\title{
Nitrogen-containing heterocycles: 1,3-dipolar cycloaddition of stabilized nitrones with alkynes; primary cycloadducts, first and second generation rearrangement processes
}

\author{
Frances Heaney, ${ }^{* a}$ Julie Fenlon, ${ }^{b}$ Colm O’Mahony ${ }^{b}$ Patrick McArdle ${ }^{b}$ and \\ Desmond Cunningham ${ }^{b}$ \\ ${ }^{a}$ Department of Chemistry, National University of Ireland, Maynooth, Ireland
${ }^{b}$ Department of Chemistry, National University of Ireland, Galway, Ireland
}

Received (in Cambridge, UK) 27th July 2001, Accepted 10th September 2001

First published as an Advance Article on the web 28th November 2001

[4.3.0]- and [5.3.0]Bicyclic ring systems containing a nitrogen atom at the bridgehead position were prepared by a $[3+2]$ addition of acetylenic dipolarophiles to the conformationally locked cyclic $\alpha$-alkoxycarbonylnitrones $\mathbf{1 a - c}$ and 18. Reaction proceeded with a high degree of diastereofacial selectivity with cycloaddition taking place to the face of the dipole opposite the C-5 methyl group. Reaction with the $C$-phenyl nitrones, $\mathbf{1 b}$ and 1c, was straightforward and the structure of $\mathbf{1 2} \mathbf{b}$, arising from reaction of $\mathbf{1 b}$ with dimethyl acetylenedicarboxylate has been determined by single crystal X-ray diffraction. The identity of the product(s) from reaction of $C$-methyl nitrones, $\mathbf{1 a}$ or 18, with dimethyl acetylenedicarboxylate varies with reaction duration; 12a and $\mathbf{2 0}$ are the primary cycloaddition products and the pyrrolooxazinones $\mathbf{1 4}$ and $\mathbf{2 2}$ appear after prolonged reaction duration. A similar pattern of reactivity is observed when the same dipoles react with methyl propiolate. The structure of $\mathbf{1 4}$ has been confirmed following X-ray crystallographic analysis. The primary cycloadducts, 12a, 20, 24a and 30, bearing a C3a-methyl group had poor thermal stability and rearranged to the pyrrolooxazinones 13, 21, 25 and 31 respectively. A mechanistic proposal for the origin of the fused pyrroles is included. A C-6 methyl substituent on the dipole $\mathbf{1 8}$ had no determining influence on the stereochemical course or the rate of the cycloaddition reaction established by its unsubstituted analogues 1a and $\mathbf{1 b}$. In addition to its mechanistic findings, this paper reports two significant synthetic advances: access to a range of unusually substituted hetero-fused pyrroles and to isoxazolooxazepinones, a rare bicyclic ring system.

\section{Introduction}

The 1,3-dipolar cycloaddition reaction of nitrones and nitrile oxides is amongst the most important methodologies for the construction of $N$-containing heterocycles. ${ }^{1}$ We have recently reported the ready preparation of the $E$-geometry fixed cyclic dipoles 1 by thermal cyclization of the corresponding $E$-alkenyl oximes. "Lactone" containing nitrones like $\mathbf{1}$ are relatively rare, however synthesis of their 5-membered analogues has been reported; reaction of isonitroso Meldrum's acid with ketones forms 2 in moderate yield. ${ }^{3}$ Tamura's group have prepared the C-5 phenyloxazinone $N$-oxide 4 by indirect oxidation of $R$-phenylglycinol followed by condensation with methyl glyoxylate, ${ }^{4}$ whilst Baldwin and co-workers report formation of the same dipole by direct oxidation (dimethyldioxirane, 3-4 equivalents) of oxazinone $3 .^{5 a}$ Looper and Williams report the success of Davis' oxaziridine for oxidation of analogues of $3,{ }^{5 b}$ and finally, $\mathbf{6}$, the lactam analogue of $\mathbf{1}$ has been accessed by oxidation $\left(\mathrm{H}_{2} \mathrm{O}_{2}, \mathrm{Na}_{2} \mathrm{WO}_{4}\right)$ of the pyrazinone 5. ${ }^{6}$ Related dipoles, the azomethine ylides 7 have been extensively studied by Harwood et l. $^{7}$ and preparation and cycloaddition of the azomethine imine $\mathbf{8}$ has recently been reported. ${ }^{8}$ Ali and Wazeer have shown earlier that the introduction of an $\alpha$-keto substituent lowers the reactivity of the cyclic nitrone 9 compared to the parent $10,{ }^{9} \dagger$ whilst the presence of a $\beta$-heteroatom makes 11a more reactive than the carbocyclic analogue. ${ }^{10 a}+$ Finally, a

$\dagger$ It is reported that bond opposition strain in the transition state leading to cycloaddition and a lower dipole moment combine to render the $\alpha$-keto dipole a less reactive species.

$\$$ It is proposed that the skeletal oxygen atom may have a defining influence on the conformation of the heterocyclic dipole and that the torsional strain relieved when it undergoes cycloaddition will be greater than that associated with addition to the carbocyclic analogue. $\gamma$-heteroatom, as in $\mathbf{1 1 b}$, appears to have little influence on reactivity. ${ }^{10 b, c}$ The influence of the lactone/lactam moiety on the cycloadditive potential of the dipoles $4,6,7$ and 8 has been to reduce their reactivity and high pressure, long reaction times or Lewis acid catalysts have generally been employed to promote reaction. The nitrones 1 and 18, unlike their sister dipoles 2, 4, 6 and 7 , are $C$-substituted and consequently cycloaddition could be slow, but it should lead to highly substituted isoxazolooxazinones. We now report our findings on the reaction of 1 and 18 with electron poor acetylenes and the tendency of the primary cycloadducts to participate in rearrangement reactions.<smiles>[R]C(=NO)C(=O)O[Ga]CCCC</smiles><smiles>[R]C(=O)[NH+]=C1C(=O)OC(C)(C)OC1=O</smiles>

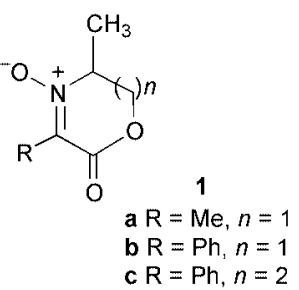

c R $=\mathrm{Ph}, n=2$

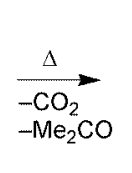<smiles>[R]C1OC(=O)C=[N+]1[O-]</smiles>

\section{Results and discussion}

Following stirring in boiling $\mathrm{CHCl}_{3}(30 \mathrm{~h})$ the dipole 1a reacts with dimethyl acetylenedicarboxylate (1.5 eq.) in a diastereofacially specific manner furnishing $\mathbf{1 2 a}$ as the only reaction 
Table 1 Selected ${ }^{1} \mathrm{H}$ NMR spectral data for the isoxazolooxazinones $12,15,23,24$ and $23 \mathrm{c}$

\begin{tabular}{lllll}
\hline & \multicolumn{1}{l}{${ }^{1} \mathrm{H}$ NMR position $(\mathrm{ppm})\left[{ }^{3} J_{6,7},{ }^{3} J_{6,6} / \mathrm{Hz}\right]$} & & \\
\cline { 2 - 5 } Adduct & $6 \mathrm{a}-\mathrm{H}$ & $6 \mathrm{~b}-\mathrm{H}$ & $7-\mathrm{H}$ & $2-\mathrm{H} / 3-\mathrm{H}$ \\
\hline $\mathbf{1 2 a}$ & $4.30[2.93,12.02]$ & $4.10[9.40,12.02]$ & 3.45 & - \\
$\mathbf{1 2 b}$ & $4.14[3.17,11.96]$ & $3.85[10.99,11.96]$ & 3.62 & - \\
$\mathbf{1 5}$ & $4.33[3.17,11.72]$ & $4.68[9.52,11.72]$ & 3.72 & - \\
$\mathbf{2 3 a}$ & $4.46[2.69,12.02]$ & $4.16[6.84,12.02]$ & 3.48 & 7.38 \\
$\mathbf{2 4 a}$ & $4.25[2.93,11.96]$ & $4.05[11.96,11.96]$ & 3.32 & 6.00 \\
23b & $4.05[3.17,11.96]$ & $3.73[11.23,11.96]$ & 3.57 & 7.48 \\
24b & $4.20[2.93,11.96]$ & $4.04[10.74,11.96]$ & 3.54 & 6.26 \\
23c & $4.24[3.05,11.60]$ & $4.57[9.77,11.60]$ & 3.65 & 7.19 \\
\hline
\end{tabular}
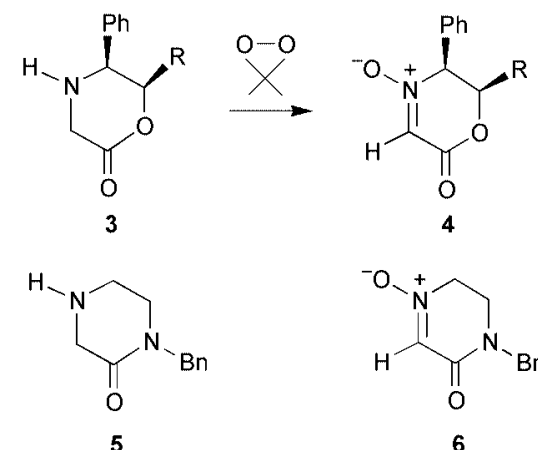<smiles>CO[N+]1=CCN(Br)C(=O)C1</smiles><smiles>[R]C=[N+](C)[C@@H](C)[C@H]1COC(=O)C[C@H]1C</smiles><smiles>CN1C(=O)OC[C@H](c2ccccc2)[N+]1=Cc1ccccc1</smiles>

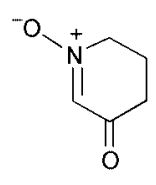

9

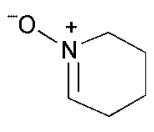

10

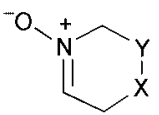

11a $X=O, Y=\mathrm{CH}_{2}$ b $\mathrm{X}=\mathrm{CH}_{2}, \mathrm{Y}=\mathrm{O}$ product. Nuclear Overhauser enhancement difference spectroscopy (NOEDS) experiments gave only a weak indication as to the relative stereochemistry of $\mathbf{1 2 a}$, which, following comparison with ${ }^{1} \mathrm{H}$ NMR spectral data of the analogous adducts $\mathbf{1 2 b}$ and $\mathbf{1 5}$ (Table 1), is tentatively assigned as shown in the drawing. Although 12a is stable either as a solid or in solution at $\mathrm{rt}$, efforts to recrystallise it [from $\mathrm{CHCl}_{3}$ (wet or $d r y$ ) or $\mathrm{C}_{6} \mathrm{H}_{6}$ ] alerted us to its very limited thermal stability. It was subsequently found that following heating alone in boiling $\mathrm{CHCl}_{3}$ $(25 \mathrm{~h})$ 12a completely disappeared and the pyrrolo-fused bicycle 13 was isolated in $80 \%$ yield. $\Delta^{4}$-Isoxazolines are well recognised as labile heterocycles ${ }^{11 a}$ and their ring opening reactions have been synthetically exploited. ${ }^{11 b}$ Recent experiments support the involvement of acylaziridines and azomethine ylides as intermediates in the ring transformation of isoxazolines, ${ }^{11 c, d}$ and one possible route to the pyrrole nucleus from the aziridine is detailed in Scheme 1. In an effort to obtain $\mathbf{1 3}$ directly from reaction of 1a with dimethyl acetylenedicarboxylate, the original reaction was repeated extending the time to $48 \mathrm{~h}$. Following purification of the product mixture two adducts were isolated: the primary cycloadduct $\mathbf{1 2 a}(25 \%)$ and a second compound $(31 \%)$, not 13 , but rather a new product with ${ }^{1} \mathrm{H}$ NMR spectral data similar to $\mathbf{1 3}$ with two exceptions - the loss of the "aromatic" pyrrole $\mathrm{H}$ signal $\left(\delta_{\mathrm{H}} 7.29 \mathrm{ppm}\right)$ and the presence of an additional methoxy resonance signal. To the new adduct we assigned structure $\mathbf{1 4}$. A crystal of $\mathbf{1 4}$ suitable for $\mathrm{X}$-ray analysis was obtained following slow evaporation of $\mathrm{C}_{6} \mathrm{H}_{6}$ and confirmation that it has a 1-oxo-3,4-dihydro- $1 H$-pyrrolo[2,1-c][1,4]oxazinone framework rests with this structure determination. The ORTEX drawing of $\mathbf{1 4}$ is shown in Fig. 1. The pyrrole ring,

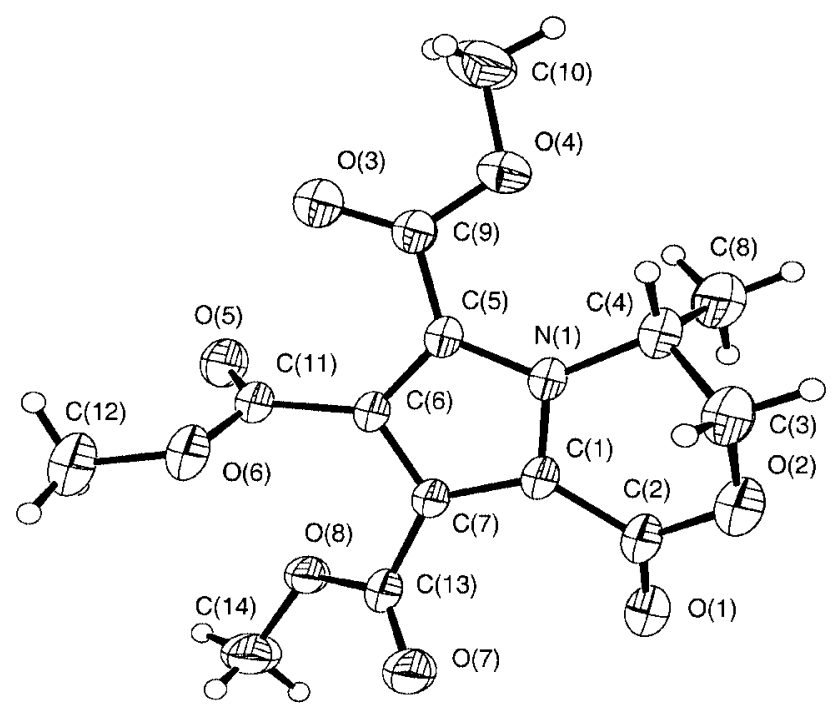

Fig. 1 ORTEX drawing of compound 14.

as expected, is planar (mean deviation from planarity $0.04 \AA$ ), and 4-C and 2-C (crystal numbering system) are on opposite sides of the plane by just $0.9 \AA$. The estimated dihedral angles $3 \mathrm{aH}-\mathrm{C}-\mathrm{C}-4 \mathrm{H},-63.32^{\circ}(0.32)$ and $3 \mathrm{bH}-\mathrm{C}-\mathrm{C}-4 \mathrm{H}, 54.73^{\circ}(0.32)$ are not as would be expected from analysis of the vicinal coupling constants ${ }^{3} J_{3,4}$ of $\mathbf{1 4}$. The apparent failure of the NMR and crystallographic data to correlate simply means that the sixmembered ring adopts a different conformation in solution than in the solid state. The 1-oxo-3,4-dihydro- $1 H$-pyrrolo$[2,1-c][1,4]$ oxazinone framework of $\mathbf{1 4}$ has previously been accessed by Harwood and Lilly following aromatisation of the reaction product of azomethine ylide $7\left(\mathrm{R}=\mathrm{CO}_{2} \mathrm{Et}\right)$ with methyl propiolate. ${ }^{7 b}$

Initially, it seemed likely that $\mathbf{1 4}$ may arise via $\mathbf{1 3}$ by way of a direct cycloaddition-cycloreversion sequence involving a [4+2] addition of the pyrrole nucleus to a second equivalent of dimethyl acetylenedicarboxylate, followed by elimination of a molecule of methyl propiolate (Scheme 2, path A). Dimethyl acetylenedicarboxylate is a reactive dienophile and the involvement of $\mathbf{1 3}$ in a Diels-Alder reaction could be considered to be facilitated by the following structural features. The 2- and 5-positions of the pyrrole ring are already substituted, therefore, Michael type addition is not an attractive option. The pyrrole nitrogen atom is substituted thus lowering the activation energy for the [4+2] cycloaddition. Finally the conjugating substituents in $\mathbf{1 3}$ lower the aromaticity of the pyrrole nucleus further permitting it to function as a diene in a DielsAlder reaction..$^{12}$ Despite these characteristics it was discovered that independent heating of $\mathbf{1 3}$ with dimethyl acetylenedicarboxylate failed to furnish any $\mathbf{1 4}$. This result suggests a critical role for unreacted nitrone in the formation of $\mathbf{1 4}$ and our revised mechanism (Scheme 2, path B) follows from a series of reactions with 21, the 3-methyl analogue of 13; these observations will be discussed below.

The reaction of $C$-phenyl dipole $\mathbf{1 b}$ with dimethyl acetylenedicarboxylate progressed more slowly than its methyl analogue and some unreacted nitrone $(26 \%)$ was present even after $40 \mathrm{~h}$ heating. The diastereomeric products $\mathbf{1 2 b}$ and $\mathbf{1 5}$ were obtained in a ratio of $10: 1$. The $\mathrm{C}-3$ a position carries a phenyl substituent and hence there exists no opportunity for $\mathbf{1 2 b}$ or $\mathbf{1 5}$ to form pyrrolo-fused adducts in an analogous fashion to 13 or 14 . As 


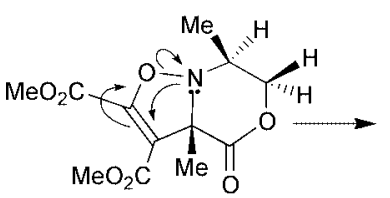

$12 a$

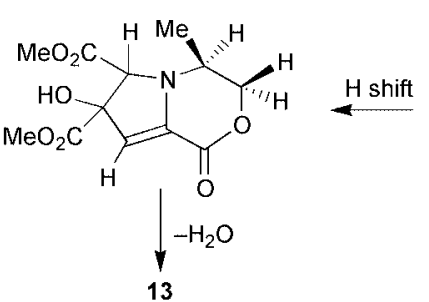

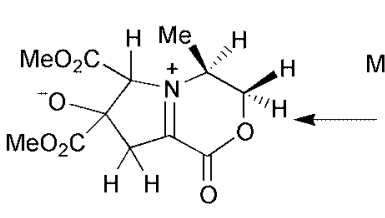
$\mathrm{MeO}_{2} \mathrm{C}$

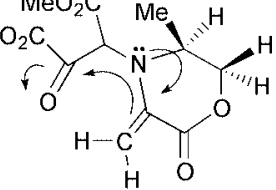

Scheme 1<smiles>[R]C1OC(O)c2cc(F)c(F)n2C(C)C1C#CCF</smiles>

Path A

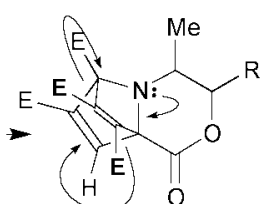

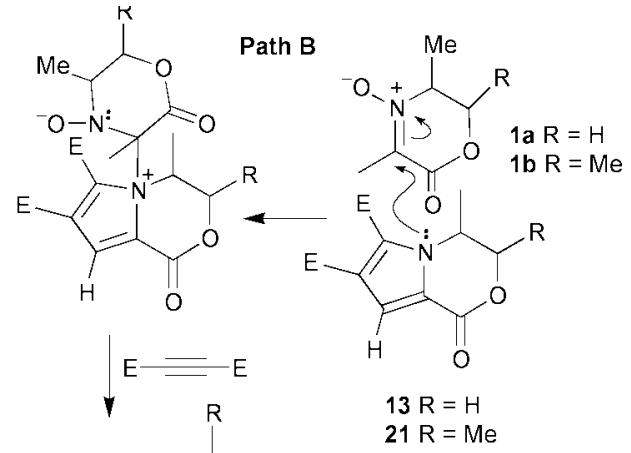

$\mathrm{R}=\mathrm{Me}$<smiles>c1ccccc#1</smiles>

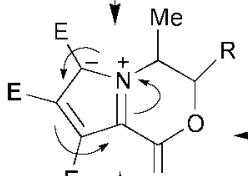

$\mathrm{E}=\mathrm{H}$<smiles>CCCCOCCO</smiles>

$21 \mathrm{R}=\mathrm{Me}$

Scheme 2
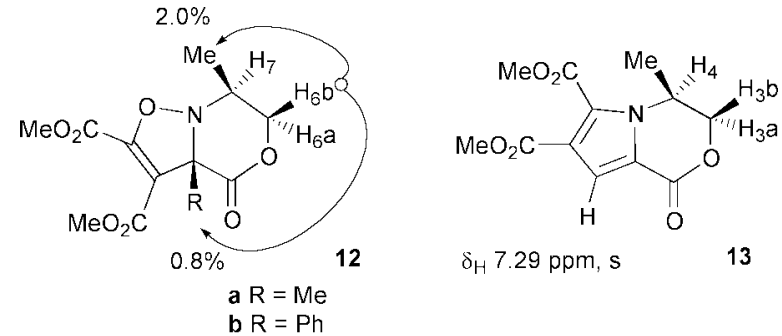

$\delta_{H} 7.29 \mathrm{ppm}, \mathrm{s}$

13

NOEDS Results shown for $12 a$

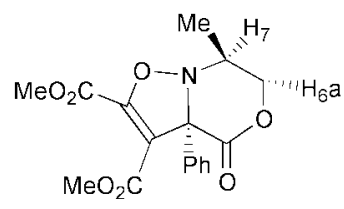

15

was observed for 12a, NOEDS results were inconclusive $(0.8 \%$ NOE between 7-Me and the 3a-ArH). However, the relative stereochemistry of $\mathbf{1 2 b}$ was confirmed following a single crystal
X-ray analysis. A crystal suitable for structure determination was obtained following slow solvent evaporation $\left(\mathrm{CHCl}_{3}-\right.$ hexane) and the ORTEX drawing of $\mathbf{1 2 b}$ is shown in Fig. 2. The isoxazoline ring is quite flat with a mean deviation from planarity of $0.1 \AA$ and the angle this ring makes with the plane defined by $\mathrm{C}(10)-\mathrm{N}(1)-\mathrm{C}(1)-\mathrm{C}(8)$ (crystal numbering system) is $63.0^{\circ}$. The dihedral angles $9 \mathrm{bH}-\mathrm{C}-\mathrm{C}-10 \mathrm{H}$ and $9 \mathrm{aH}-\mathrm{C}-\mathrm{C}-10 \mathrm{H}$ are estimated as $-69.53^{\circ}(0.53)$ and $172.95^{\circ}(0.41)$, respectively. These angles correlate well with the observed vicinal coupling in $12 \mathbf{b}^{3} J_{6 \mathbf{a}, 7}(3.17 \mathrm{~Hz})$ and ${ }^{3} J_{6 \mathbf{b}, 7}(10.99 \mathrm{~Hz})$ suggesting that in this adduct the oxazinone ring adopts a similar conformation in the solid and the solution state. From the product structure it is clear that 12b arises via addition of the dipolarophile to the least hindered $(\alpha)$ face of the dipole. The same facial specificity has previously been observed in the addition of olefinic substrates to the chiral dipoles $\mathbf{4}$ and 7. In the reported cases the C-5 "directing" group is a bulky phenyl substituent, ${ }^{4,5 a, 7 c-e, 13}$ but in the current example the smaller methyl substituent is quite effective in shielding one $\pi$-face of the dipole. NOEDS results on the minor diastereomer $\mathbf{1 5}$ were also inconclusive, however, it must, by default, have the $\mathrm{C}-3 \mathrm{a}$ and the $\mathrm{C}-7$ substituents on 


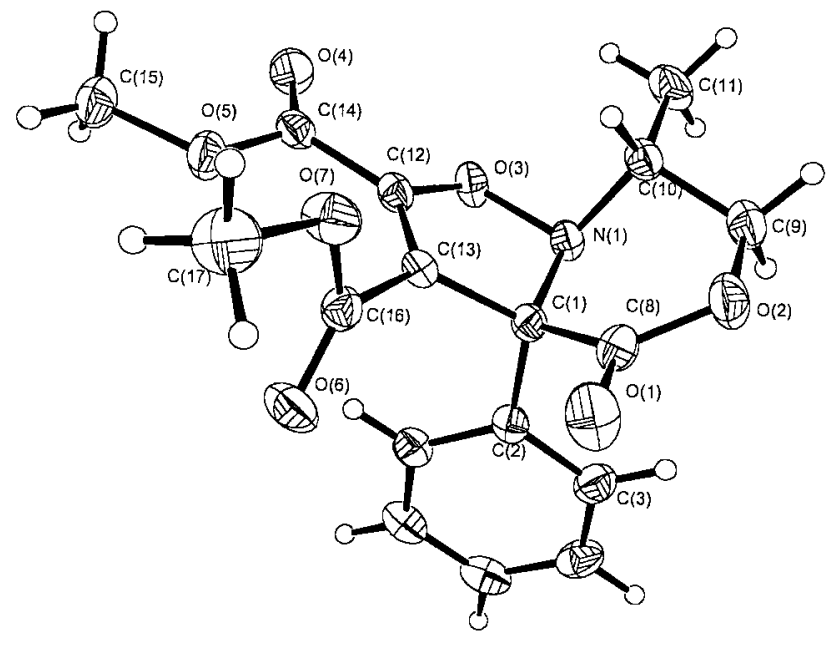

Fig. 2 ORTEX drawing of compound $\mathbf{1 2 b}$.

opposite faces. The change in relative stereochemistry between $\mathbf{1 2 b}$ and $\mathbf{1 5}$ is reflected in the resonance position of the 6bproton; in 12b this proton is shielded by the phenyl ring $(\delta 3.85$ ppm) whilst in 15 it resonates further downfield ( $\delta 4.68 \mathrm{ppm})$ (Table 1).

The 7-membered cyclic nitrone 1c reacted with dimethyl acetylenedicarboxylate (1.3 eq.) in a diastereofacially specific manner and the isoxazolooxazepinone $\mathbf{1 6}$ was isolated in $87 \%$ yield $\left(\mathrm{CHCl}_{3}, 32 \mathrm{~h}\right)$. Apart from our previous report, the 7,5bicyclic skeleton of $\mathbf{1 6}$ remains unknown. ${ }^{2}$<smiles>COC(=O)C1=C(C(C)=O)ON2[C@H]([14CH3])CCOC(=O)[C@H]12</smiles>

16<smiles>CC1=[N+]([O-])[C@@](C)(CCO)[C@](C)(O)OC1=O</smiles>

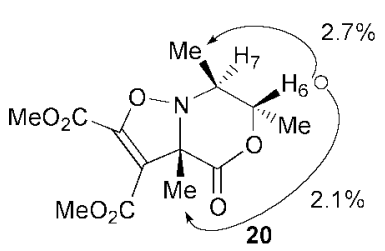<smiles>COCc1c(C(=O)OC)c(C(C)=O)n2c1C(=O)O[C@@H](C)C2(C)C</smiles>

The nitrone 18 was prepared in order to observe the influence of a C-6 dipole substituent on the diastereoselectivity of the cycloaddition reaction. Pyruvic acid was allowed to react with but-3-en-2-ol and the resulting ester 17a upon treatment with $\mathrm{NH}_{2} \mathrm{OH}$ afforded the oxime 17b. Thermal cyclisation (xylene, $140{ }^{\circ} \mathrm{C}, 51 \mathrm{~h}$ ) of $\mathbf{1 7 b}$ proceeded with a moderate degree of facial selectivity, generating the diastereomeric dipoles 18 and 19 in the ratio $10: 3$. The major nitrone, 18, has the C-5 methyl group shielding one face of the dipole and the C-6 substituent shielding the opposite face (NOEDS results are summarised in the drawings). The cycloaddition of $\mathbf{1 8}$ with dimethyl acetylene- dicarboxylate gave $\mathbf{2 0}$ in 74\% yield after 7.5 h heating in boiling $\mathrm{CHCl}_{3}$. As expected, reaction at $\mathrm{rt}$ was much slower, however, almost quantitative yield resulted after $7 \mathrm{~d}$. Analysis of the NOEDS results for $\mathbf{2 0}$ clearly indicates that the dipolarophile added to the face of the dipole opposite the C-5 substituent. The rate and diastereoselectivity of reaction of $\mathbf{1 8}$ with dimethyl acetylenedicarboxylate compare favourably with those observed for the C-6 unsubstituted analogues 1a and 1b. In contrast, Baldwin et al. ${ }^{5 a}$ note a much reduced reaction rate and almost complete loss of stereoselectivity when cycloaddition to the diphenyl nitrone $\mathbf{4 b}$ is compared to reaction with the monosubstituted dipole $\mathbf{4 a}$.

The primary adduct $\mathbf{2 0}$ has limited thermal stability and heating in the minimum amount of boiling $\mathrm{CHCl}_{3}$ effects rearrangement to the pyrrolo-fused oxazinone 21 (76\%). If reaction between nitrone $\mathbf{1 8}$ and dimethyl acetylenedicarboxylate is allowed to continue for $24 \mathrm{~h}$ at reflux or $10 \mathrm{~d}$ at $\mathrm{rt}$ the pyrrolo-fused adduct $\mathbf{2 2}$ accompanies the primary cycloadduct 20. We believe that $\mathbf{2 0}$ relates to $\mathbf{2 1}$ and $\mathbf{2 2}$ in the same way as 12a relates to $\mathbf{1 3}$ and $\mathbf{1 4}$. It is our proposal that $\mathbf{2 1}$, the initial product of a thermal rearrangement of the primary cycloadduct 20, subsequently serves as a precursor to $\mathbf{2 2}$. The original proposal that $\mathbf{2 1}$ would lead directly to $\mathbf{2 2}$ (Scheme 2, path A) was revised when simple heating of $\mathbf{2 1}$ with dimethyl acetylenedicarboxylate failed to give any new product. It was only when free nitrone $\mathbf{1 8}(10 \mathrm{~mol} \%)$ was added to an equimolar mixture of $\mathbf{2 1}$ and dimethyl acetylenedicarboxylate that any trace of the pyrrole 22 became evident. After heating for $28 \mathrm{~h}$ in boiling $\mathrm{CHCl}_{3}$ the ${ }^{1} \mathrm{H}$ NMR spectrum of the crude reaction mixture shows signals characteristic of the tris(methoxycarbonyl)pyrrole 22 (5.03 ppm, m, 3-H and 3.91, s, OMe); the relative intensities of the diagnostic signals for $\mathbf{2 1}$ and $\mathbf{2 2}$ suggest they are present in a $\sim 7: 1$ ratio. These experimental results suggest that, despite the structural attributes listed above, the pyrrole nucleus of $\mathbf{2 1}$ (or 13) is too unreactive to form a Diels-Alder adduct with dimethyl acetylenedicarboxylate and the first step in the generation of $\mathbf{2 2}$ (or 14) is likely the quaternisation of the pyrrole nitrogen atom by nucleophilic attack on the nitrone. The $N$-protonated species is more susceptible to a cycloaddition-cycloreversion process, which ultimately leads to $\mathbf{2 2}$ (Scheme 2, path B). The origin of $\mathbf{1 4}$ likely mirrors that of 22 and the prolonged reaction of dipoles like 1a and $\mathbf{1 8}$ with dimethyl acetylenedicarboxylate may represent a useful route to unusually substituted hetero-fused pyrroles.

One interesting feature of the ${ }^{1} \mathrm{H}$ NMR spectrum $\left(\mathrm{CDCl}_{3}\right)$ of 21 is the appearance of the signals for $3-\mathrm{H}$ and $4-\mathrm{H}$ as quartets rather than the expected doublet of quartets. The implication is that each of these protons is spin coupled only to the adjacent Me group with there being zero coupling between 3-H and 4-H and indeed decoupling experiments are in complete agreement with this conclusion. Clearly when in solution in $\mathrm{CDCl}_{3} 21$ must adopt a conformation where the dihedral angle $3-\mathrm{H}-\mathrm{C}-\mathrm{C}-4-\mathrm{H}$ would result in $J=0$. Interestingly, no changes were observed in the general appearance of the spectrum upon changing the NMR solvent to $\mathrm{C}_{6} \mathrm{D}_{6}$.

The dipoles 1a, $\mathbf{1 b}$ and $\mathbf{1 c}$ all reacted with methyl propiolate in boiling $\mathrm{CHCl}_{3}$ giving regioisomeric 4- and 5-substituted $\Delta^{4}$-isoxazolines. For all of the dipoles reaction with methyl propiolate was more sluggish than with dimethyl acetylenedicarboxylate and a larger excess of dipolarophile was employed to promote cycloaddition. In the case of $\mathbf{1 a}$ reaction was complete after heating for $32 \mathrm{~h}$ and the adducts $23 \mathrm{a}(56 \%)$ and 24a $(23 \%)$ were obtained. Their regiochemical assignment is obvious from the resonance position of the isoxazoline proton, 2-H/3-H (Table 1). Cycloaddition took place in a facially specific manner and only one diastereomer of each regioisomer is found. For this series of compounds the stereochemical relationship between $6 \mathrm{a} / 6 \mathrm{~b}-\mathrm{H}$ and $7-\mathrm{H}$ is based on the magnitude of the vicinal coupling constants $J_{6,7}$ where $J_{\text {ax,eq }}<J_{\text {ax,ax }}{ }^{14}$ (Table 1). That this generalisation holds for the current 
structures is supported by comparison between the crystallographic and the NMR spectral measurements for 12b. NOEDS experiments on 23a indicate a small enhancement $(\sim 0.5 \%)$ on $6 \mathrm{~b}-\mathrm{H}$ following irradiation of $3 \mathrm{a}-\mathrm{Me}$, and as $6 \mathrm{~b}-\mathrm{H}$ is cis to $7-\mathrm{Me}$ it follows that the 3a- and 7-methyl groups lie on the same face of the molecule. Regioselective formation of the 4-substituted adduct (isoxazolidine numbering) is in keeping with literature precedent for the addition of acetylenes to $C$-substituted nitrones. ${ }^{15}$ The relative stereochemistry of the minor adduct $\mathbf{2 4 a}$ remains unknown as NOEDS results were inconclusive.
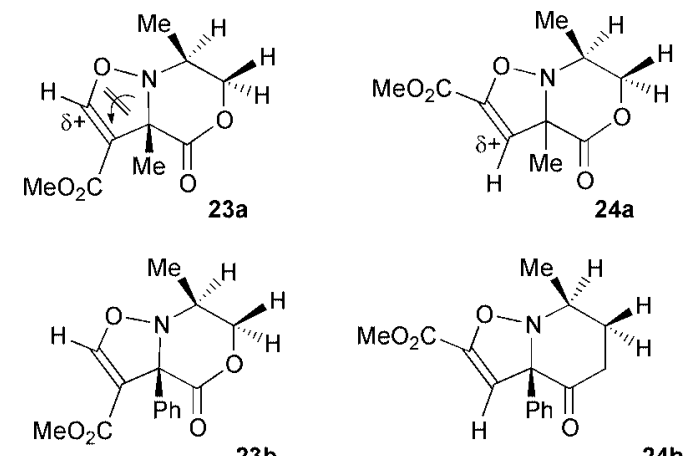

$24 b$

The adduct $\mathbf{2 4 a}$, by virtue of the direction of polarisation of the conjugated "double bond" of its isoxazoline ring, is activated to acylaziridine formation, and on thermal activation it converts to the pyrrolooxazinone $\mathbf{2 5}$. The rate and extent of the transformation are significantly reduced $(40 \%, 56 \mathrm{~h})$, but it most likely proceeds by a mechanism parallel to that outlined for 12a $(80 \%, 25 \mathrm{~h})$ in Scheme 1. The adduct 23a is not activated toward acylaziridine formation in the same way as its regioisomer and it is thermally stable after $24 \mathrm{~h}$ heating in boiling $\mathrm{CHCl}_{3}$. However, inspection of the crude ${ }^{1} \mathrm{H}$ NMR spectrum of the mixture after $82 \mathrm{~h}$ heating it is clear that very little of 23a remains intact and whilst much decomposition has occurred one new compound can be seen. This material, present in a $5: 1$ ratio with 23a has been isolated and characterised as the pyrrole 26a. The pyrrolooxazinone 26a likely arises from 23a as shown in Scheme 3, a homolytic cleavage of the isoxazoline $\mathrm{N}-\mathrm{O}$ bond

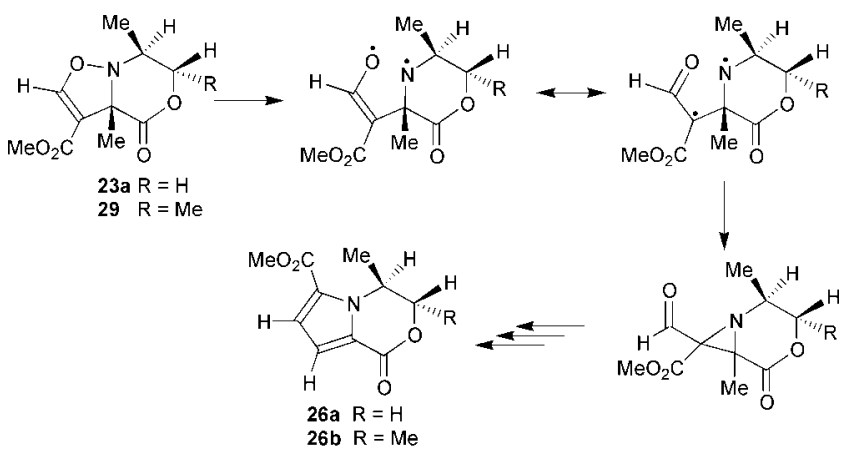

Scheme 3

of 23a generates a diradical species which is a precursor to the acylaziridine, the mechanism for formation of the pyrrole ring from the acylaziridine intermediate is as delinated for $\mathbf{1 3}$ in Scheme 1.

As previously observed in the reaction of $C$-methyl dipoles with dimethyl acetylenedicarboxylate, the composition of the products of reaction between 1a and methyl propiolate is dependent on reaction duration. After $82 \mathrm{~h}$ at reflux the ${ }^{1} \mathrm{H}$ NMR spectrum of the crude mixture clearly shows signals characteristic of the primary adduct $\mathbf{2 4 a}(6.00 \mathrm{ppm}, \mathrm{s}, 3-\mathrm{H})$ as well as a pair of doublets, 7.49 and $7.52 \mathrm{ppm}$ each with a small $J$ value $(1.5 \mathrm{~Hz})$ characteristic of the meta-coupled aromatic protons of 25. A second pair of doublets in the $\mathrm{Ar}-\mathrm{H}$ region of the spectrum points to the presence of a further reaction product which we propose to have structure $\mathbf{2 5 i}$. The primary cycloadduct 23a has its $2-\mathrm{H}$ signal at $7.48 \mathrm{ppm}$ in the ${ }^{1} \mathrm{H}$ NMR spectrum and this signal has all but disappeared from the spectrum of the crude reaction mixture $(82 \mathrm{~h})$ and a new signal presented at $7.36 \mathrm{ppm}$. Following flash chromatography it became evident that the aforementioned signal was representative of an inseparable mixture of isomeric pyrroles identified as $\mathbf{1 3}$ and 13i. Integration of signals characteristic of each compound suggests the components to be present in the following approximate ratios 24a : 23a : $25: \mathbf{2 5 i}: \mathbf{1 3}$ plus 13i $3:$ trace : 15 : $4: 25$.

The pyrrole $\mathbf{2 5}$ could have its origins in a straightforward thermal rearrangement of $\mathbf{2 4 a}$, akin to the observed transformation of 12a to 13. However, this is probably not the case since the corresponding reaction of dipoles $1 \mathbf{a}$ and $\mathbf{1 8}$ with dimethyl acetylenedicarboxylate did not stop with the products of a simple thermal reaction (13 and $\mathbf{2 1}$ ), but rather continued in a more complex process furnishing instead 14 and 22 . This apparent anomaly is satisfied by considering that if pyrrole $\mathbf{2 5}$ were to participate in an activation-addition-elimination sequence of the type proposed for $\mathbf{1 3}$ and $\mathbf{2 1}$ (Scheme 2, path B), the unsymmetrical nature of methyl propiolate should result in the formation of two regioisomeric Diels-Alder cycloadducts A and $\mathbf{B}$. Elimination from $\mathbf{A}$ would return $\mathbf{2 5}$ and therefore the process would be degenerate. However, elimination from B would afford the isomeric compound 25i. Evidence to support the structure of $25 \mathrm{i}$ lies with the crude ${ }^{1} \mathrm{H}$ NMR spectral data which clearly show a pair of doublets, 7.05 and $6.96 \mathrm{ppm}$ with $J 4.4 \mathrm{~Hz}$, typical of ortho-related protons on a pyrrole ring.

The pyrrolooxazinones $\mathbf{1 3}$ and 13i likely arise from 23a in a parallel fashion i.e. an initial thermal rearrangement of 23a to the pyrrolo-fused adduct 26a followed by an activation, DielsAlder cycloaddition sequence generating regioisomeric intermediates $\mathrm{C}$ and $\mathrm{D}$, methyl propiolate elimination affords $\mathbf{1 3}$ and 13 i respectively.

As observed with dimethyl acetylenedicarboxylate the phenyl substituted dipole $\mathbf{1 b}$ reacts more slowly with methyl propiolate than its counterpart and $43 \%$ nitrone remained after a reaction time of $40 \mathrm{~h}$. Further $\mathbf{1 b}$ does not exhibit high diastereoselectivity in reaction with methyl propiolate and the diastereomeric 4-substituted isoxazolines $\mathbf{2 3 b}(31 \%)$ and $\mathbf{2 3}$ c (13\%) are isolated with the 5-substituted adduct 24b (17\%). For each of $\mathbf{2 3 b}$ and 24b an $\sim 3 \%$ enhancement was observed on Ar-H upon irradiation of $6 \mathrm{~b}-\mathrm{H}$, and taken together with the coupling constant data for $J_{6,7}$ the relative stereochemistry of $\mathbf{2 3 b}$ and $\mathbf{2 4 b}$ is thus assigned as shown in the diagrams. The relative stereochemistry of 23c must be opposite to that of 23b and it is assigned by default. Again it is worth noting the deshielding experienced by $6 \mathrm{~b}-\mathrm{H}$ when the relative configuration at the stereogenic centres is changed: thus, for $\mathbf{2 3 b}$ and $\mathbf{2 4 b} 6 \mathbf{b}-\mathrm{H}$ resonates at $\sim \delta 4.0 \mathrm{ppm}$ whilst the same proton in $23 \mathrm{c}$ appears at $\delta 4.57$ ppm (Table 1).

To encourage reaction of 1c with methyl propiolate it was necessary to employ a great excess of dipolarophile and accordingly methyl propiolate was used as both reactant and solvent. After $36 \mathrm{~h}$ the regioisomeric 4- and 5-substituted $\Delta^{4}$-isoxazolines 27 and 28 were formed in 24 and $60 \%$ yield respectively. The similarity between the ${ }^{1} \mathrm{H}$ NMR spectral data of the three [5.3.0]bicyclic adducts 16, 27 and 28 suggests that all the cycloadditions took place with the same stereochemical sense (Table 2).

Table 2 Selected ${ }^{1} \mathrm{H}$ NMR spectral data for the isoxazolooxazepinones 16,27 and 28

\begin{tabular}{|c|c|c|c|c|}
\hline \multirow[b]{2}{*}{ Adduct } & \multicolumn{4}{|l|}{$\delta_{\mathrm{H}}(\mathrm{ppm})$} \\
\hline & $6 \mathrm{a}-\mathrm{H}$ and $6 \mathrm{~b}-\mathrm{H}$ & $7 \mathrm{a}-\mathrm{H}$ & 7b-H & $8-\mathrm{H}$ \\
\hline 16 & $3.88(2 \mathrm{H})$ & 2.24 & 1.67 & 3.60 \\
\hline 27 & $3.86(2 \mathrm{H})$ & 2.21 & 1.64 & 3.50 \\
\hline 28 & $4.10(1 \mathrm{H})$ and $3.90(1 \mathrm{H})$ & 2.23 & 1.75 & 3.52 \\
\hline
\end{tabular}



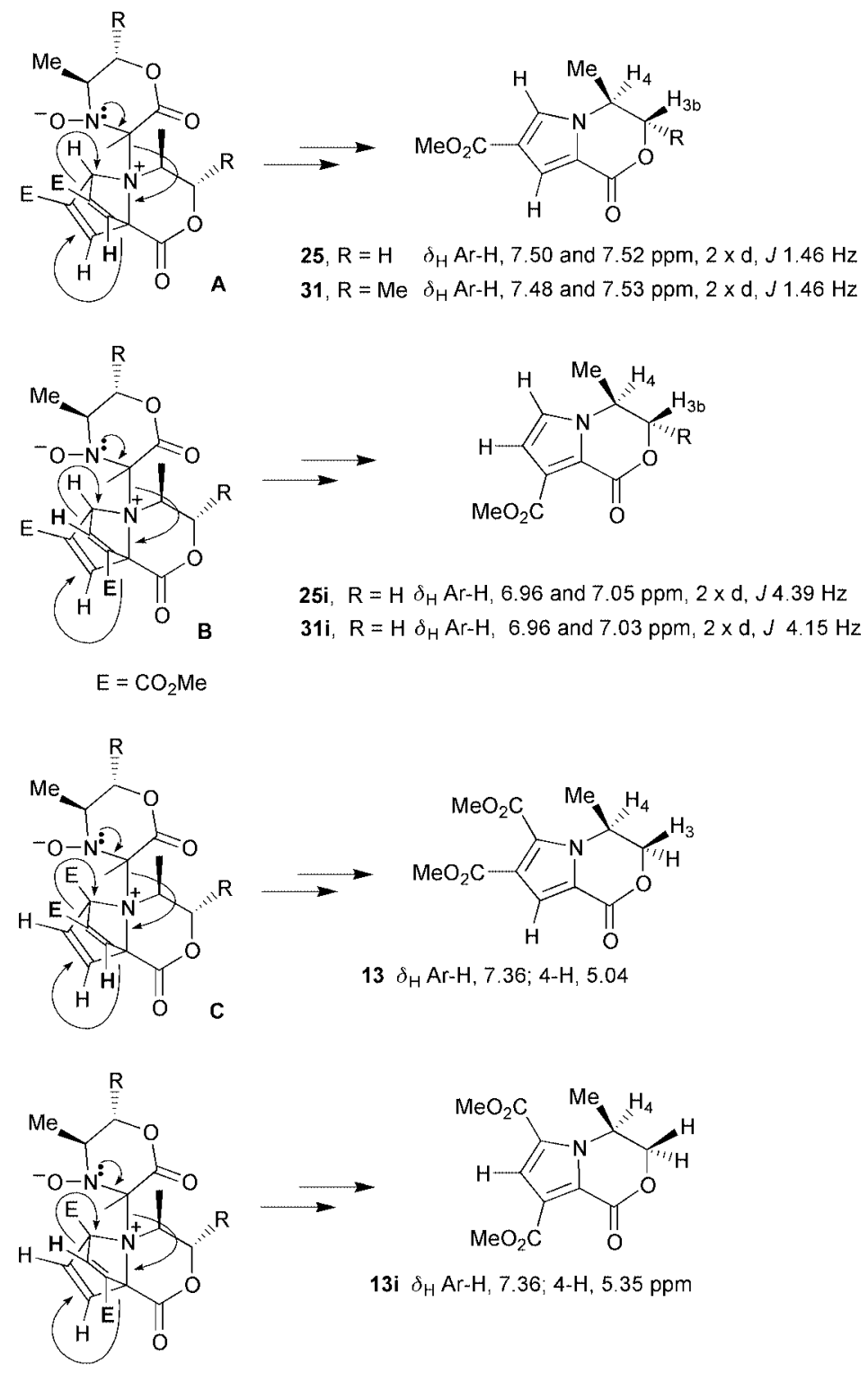

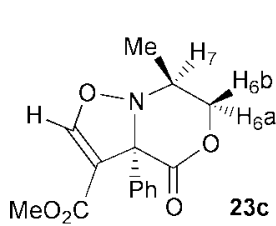<smiles>CCCCCC(C)C(C)=O</smiles><smiles>CC(=O)C1=C(c2ccccc2)[C@@H]2C(=O)OCC[C@H](N1)[C@@H]2O</smiles>
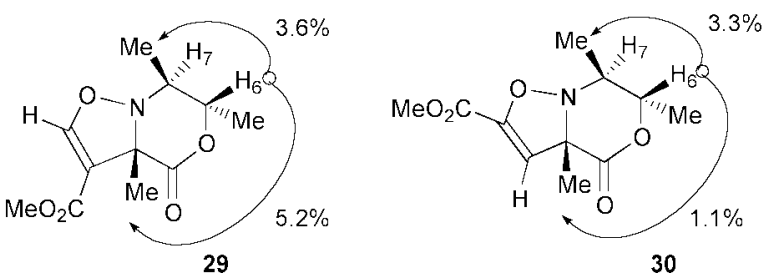

To promote reaction between the fully substituted nitrone $\mathbf{1 8}$ and methyl propiolate, the reactants were heated in refluxing $\mathrm{CHCl}_{3}(30 \mathrm{~h})$. As with 1a, the 4-substituted isoxazoline is the major regioisomer and $\mathbf{2 9}$ and $\mathbf{3 0}$ were isolated in the ratio $3: 2$. NOEDS results indicate that the new adducts have the same relative stereochemistry and that in each case cycloaddition proceeded through a transition state involving the dipolarophile approaching the dipole on the face opposite the C-5 methyl group. The direction of polarisation of the isoxazoline $\mathrm{C}=\mathrm{C}$ bond makes regioisomer $\mathbf{3 0}$ a good candidate for thermally induced acylaziridine formation and in keeping with the reactivity of its sister compounds $\mathbf{1 2 a}, \mathbf{2 0}$ and $\mathbf{2 4 a}$, it rearranges to the pyrrole $31(67 \%)$ following heating in boiling $\mathrm{CHCl}_{3}$. The isomeric adduct 29, like its sister compound 23a, is less prone to thermal rearrangement, remaining intact after $24 \mathrm{~h}\left(\mathrm{CHCl}_{3}, 63\right.$ ${ }^{\circ} \mathrm{C}$ ). Following heating for $82 \mathrm{~h}$ some decomposition became evident, however a single new compound, the pyrrolooxazinone 26b was isolated from the reaction mixture. A proposed mechanistic origin of $\mathbf{2 6 \mathbf { b }}$ is outlined in Scheme 3. When reaction between 18 and methyl propiolate was extended to $84 \mathrm{~h}$ and the products were analysed by ${ }^{1} \mathrm{H}$ NMR spectroscopy, it was found that the regioisomeric primary cycloadducts $\mathbf{2 9}$ and $\mathbf{3 0}$ were accompanied by the pyrrole $\mathbf{3 1}$ and what is believed to be its isomer 31i. The pyrroles $\mathbf{3 1}$ and $\mathbf{3 1 i}$ are analogous with $\mathbf{2 5}$ and $25 \mathbf{i}$ and presumably share the same mechanistic origin.

It is clear from the reaction of the 3,5,6-trimethyl nitrone $\mathbf{1 8}$ with dimethyl acetylenedicarboxylate and with methyl propiolate that the stereochemical mode of reaction is the same as that observed with the less substituted nitrones 1 . The C-6 substituent on $\mathbf{1 8}$ is more remote from the dipole reacting site and it is apparent that if it is to have a chance to invert the diastereoselectivity of the cycloaddition reaction it needs to be much larger than the C-5 group. Work is progressing in this direction.

\section{Conclusion}

In conclusion, 1,3-dipolar cycloaddition of the oxazinone 
$N$-oxides 1a,b to acetylenic dipolarophiles proceeded to afford cycloadducts predominately through addition to the less substituted face of the dipole. The phenyl substituted dipole $\mathbf{1 b}$ with its enhanced conjugation is a more sluggish reactant than its methyl analogue 1a; this was reflected in longer reaction times and incomplete conversion to cycloadducts. Adducts arising from reaction of 1a, with a C-3a methyl substituent are prone to primary and secondary rearrangement processes opening a route to highly substituted pyrrolo-fused oxazinones. The seven-membered dipole 1c on trapping with the acetylenes furnished novel isoxazolooxazepinones: examples of a rare bicyclic ring system. The trapping of the trisubstituted nitrone 18 with acetylenic dipolarophiles indicates that the additional C-6 substituent had no role to play in influencing the stereochemical course of the cycloaddition. It remains to be seen if a group larger than methyl is able to override the control of the C-5 substituent. The high regio- and diastereoselectivities of the cycloaddition chemistry of $\mathbf{1}$ and $\mathbf{1 8}$ encourage us in future investigations of their chiral, non-racemic derivatives in search of enantiopure products.

\section{Experimental}

Mps were determined on an Electrothermal melting point apparatus and are uncorrected. Elemental analyses were performed on a Perkin-Elmer model $240 \mathrm{CHN}$ analyser. IR spectra (Nujol mull and liquid film) were measured on a Perkin Elmer 1600 series (FT) or a Perkin Elmer 983G spectrometer. ${ }^{1} \mathrm{H}$ and ${ }^{13} \mathrm{C}$ NMR spectra were recorded using a JEOL EX270 FT NMR spectrometer and a JEOL JNM-LA400 FT NMR spectrometer at probe temperatures with tetramethylsilane as internal reference and deuteriochloroform as solvent; $J$ values are given in hertz. Flash column chromatography was carried out on silica gel 60 (Merck 9385, 70-230 mesh) and analytical TLC plates were purchased from Merck. Samples were located by UV illumination using a portable Spectroline Hanovia lamp $(\lambda=254 \mathrm{~nm})$ or by the use of iodine staining. Mass spectra were recorded on a Profile Kratos Analytical Instrument.

\section{Dimethyl 3a,7-dimethyl-4-oxo-3a,4,6,7-tetrahydroisoxazolo- [3,2-c][1,4]oxazine-2,3-dicarboxylate 12a}

The nitrone 1a $(0.11 \mathrm{~g}, 0.78 \mathrm{mmol})$ and dimethyl acetylenedicarboxylate $(0.16 \mathrm{~g}, 1.2 \mathrm{mmol})$ were stirred in $\mathrm{CHCl}_{3}\left(24 \mathrm{~cm}^{3}\right)$ at reflux under a nitrogen atmosphere for $30 \mathrm{~h}$. The reaction mixture was cooled to $\mathrm{rt}$ and the solvent removed under reduced pressure. The yellow oily residue was purified by flash chromatography $\left(\mathrm{Et}_{2} \mathrm{O}\right.$-petroleum spirit $\left.40-60{ }^{\circ} \mathrm{C}, 2: 1\right)$ giving 12a, colourless needles $(0.18 \mathrm{~g}, 81 \%), \mathrm{mp} 99-101{ }^{\circ} \mathrm{C}$ (from $\mathrm{CHCl}_{3}$-petroleum spirit) (Found: C, 50.45; H, 5.16; N, 4.78. $\mathrm{C}_{12} \mathrm{H}_{15} \mathrm{NO}_{7}$ requires: $\left.\mathrm{C}, 50.53 ; \mathrm{H}, 5.26 ; \mathrm{N}, 4.91 \%\right) ; \delta_{\mathrm{H}}(400$ MHz) 1.29 (3H, d, J 6.35, 7-Me), $1.83(3 \mathrm{H}, \mathrm{s}, 3 \mathrm{a}-\mathrm{Me}), 3.45(1 \mathrm{H}$, $\mathrm{m}, 7-\mathrm{H}), 3.83$ and $3.87(2 \times 3 \mathrm{H}, 2 \times \mathrm{s}, 2 \times \mathrm{OMe}), 4.10(1 \mathrm{H}, \mathrm{dd}$, $J 12.02$ and $9.40,6 \mathrm{~b}-\mathrm{H}), 4.30(1 \mathrm{H}, \mathrm{dd}, J 12.02$ and $2.93,6 \mathrm{a}-\mathrm{H})$; $\delta_{\mathrm{C}}(100 \mathrm{MHz}) 14.84(7-\mathrm{Me}), 27.03$ (3a-Me), 52.63 and 53.14 (OMe), 55.73 (7-C), 67.96 (6-C), 74.49 (3a-C), 114.66 (3-C), $146.34(2-\mathrm{C}), 158.01,161.92$ and $167.27\left(\mathrm{C}=\mathrm{O}\right.$ and $\left.2 \times \mathrm{CO}_{2} \mathrm{Me}\right)$; DEPT 135 (400 MHz) 14.83 (7-Me), 27.02 (3a-Me), 52.64 $(\mathrm{OMe}), 53.17$ (OMe), 55.73 (7-C), 67.67 (6-C) and unreacted nitrone $(0.025 \mathrm{~g}, 11 \%)$.

NOEDS results: irradiation of $6 \mathrm{~b}-\mathrm{H}$ caused a $19 \%$ enhancement on its partner $6 \mathrm{a}-\mathrm{H}, 2 \%$ enhancement on $7-\mathrm{Me}$ and $0.8 \%$ on $3 a-M e$. Back irradiation of 3a-Me caused a $0.6 \%$ enhancement on $6 \mathrm{~b}-\mathrm{H}$. Irradiation of $6 \mathrm{a}-\mathrm{H}$ caused an enhancement of $5.8 \%$ on $7-\mathrm{H}$ and $23 \%$ on its partner $6 \mathrm{~b}-\mathrm{H}$.

\section{Dimethyl 4-methyl-1-oxo-3,4,6,7-tetrahydro-1 $H$-pyrrolo[2,1-c]- [1,4]oxazine-6,7-dicarboxylate 13}

The adduct 12a $(100 \mathrm{mg}, 0.35 \mathrm{mmol})$ was stirred in $\mathrm{CHCl}_{3}$ $\left(10 \mathrm{~cm}^{3}\right)$ at reflux under a nitrogen atmosphere for $25 \mathrm{~h}$. The mixture was allowed to cool to $\mathrm{rt}$ and the solvent removed under reduced pressure. The crude product was purified by flash chromatography $\left(\mathrm{Et}_{2} \mathrm{O}\right.$-petroleum spirit, $\left.1: 2\right)$ yielding 13 , colourless needles $\left(75 \mathrm{mg}, 80 \%\right.$ ), mp $116-119{ }^{\circ} \mathrm{C}$ (from $\mathrm{Et}_{2} \mathrm{O}-$ petroleum spirit) (Found: $\mathrm{C}, 53.88 ; \mathrm{H}, 4.94 ; \mathrm{N}, 4.74 . \mathrm{C}_{12} \mathrm{H}_{13} \mathrm{NO}_{6}$ requires: $\mathrm{C}, 53.93 ; \mathrm{H}, 4.87 ; \mathrm{N}, 5.24 \%) ; \delta_{\mathrm{H}}(400 \mathrm{MHz}) 1.56(3 \mathrm{H}$, $\mathrm{d}, J 6.59, \mathrm{Me}), 3.87$ and $3.94(2 \times 3 \mathrm{H}, 2 \times \mathrm{s}, 2 \times \mathrm{OMe}), 4.44(1 \mathrm{H}$, d, $J 11.96,3 \mathrm{~b}-\mathrm{H}), 4.66(1 \mathrm{H}, \mathrm{dd}, J 11.96$ and $3.17,3 \mathrm{a}-\mathrm{H}), 5.06$ $(1 \mathrm{H}, \mathrm{m}, 4-\mathrm{H}), 7.36(1 \mathrm{H}, \mathrm{s}, \mathrm{Ar}-\mathrm{H}) ; \delta_{\mathrm{C}}(100 \mathrm{MHz}) 18.83(\mathrm{Me})$, 49.15 (4-C), 52.20 and 52.71 (OMe), 70.76 (3-C), 118.35 (8-C), 118.52 (7-C), 120.90, 121.54 (8a-C, 6-C), 157.42, 160.43 and $163.62\left(2 \times \mathrm{CO}_{2} \mathrm{Me}\right.$ and $\left.\mathrm{C}=\mathrm{O}\right)$; DEPT $135(400 \mathrm{MHz}) 18.83$ (Me), 49.15 (4-C), 52.20 and 52.71 (OMe), 70.76 (-ve, 3-C), $118.35(8-\mathrm{C}), v_{\max } / \mathrm{cm}^{-1} 3138,2359,2340(\mathrm{Ar}-\mathrm{CH}), 1732,1714$, $1706(3 \times \mathrm{C}=\mathrm{O}), 1463(\mathrm{Ar} \mathrm{C}=\mathrm{C}), 1226(\mathrm{C}-\mathrm{O})$.

\section{Trimethyl 4-methyl-1-oxo-3,4-dihydro-1 $H$-pyrrolo[2,1-c][1,4]- oxazine-6,7,8-tricarboxylate 14}

The nitrone 1a $(0.30 \mathrm{~g}, 2.1 \mathrm{mmol})$ and dimethyl acetylenedicarboxylate $(0.40 \mathrm{~g}, 2.8 \mathrm{mmol})$ were stirred in $\mathrm{CHCl}_{3}\left(40 \mathrm{~cm}^{3}\right)$ at reflux under a nitrogen atmosphere for $48 \mathrm{~h}$. The reaction mixture was allowed to cool to rt and the solvent was removed under reduced pressure. The yellow oily residue was purified by flash chromatography $\left(\mathrm{Et}_{2} \mathrm{O}\right.$-petroleum spirit, $\left.1: 1\right)$ yielding 12a (148 mg, 25\%, spectral data as previously reported), 14 (209 $\mathrm{mg}, 31 \%$ ) and unreacted nitrone (32 $\mathrm{mg}, 11 \%)$. Compound 14: colourless needles, $\mathrm{mp} 99-101^{\circ} \mathrm{C}$ (from $\mathrm{C}_{6} \mathrm{H}_{6}$ ) (Found: $\mathrm{C}, 51.62$; $\mathrm{H}, 4.40 ; \mathrm{N}, 4.22 . \mathrm{C}_{14} \mathrm{H}_{15} \mathrm{NO}_{8}$ requires: $\mathrm{C}, 51.69 ; \mathrm{H}, 4.62 ; \mathrm{N}$, $4.31 \%) ; \delta_{\mathrm{H}}(400 \mathrm{MHz}) 1.59(3 \mathrm{H}, \mathrm{d}, J 6.83,4-\mathrm{Me}), 3.90(6 \mathrm{H}, \mathrm{s}$, $2 \times \mathrm{OMe}), 3.91(3 \mathrm{H}, \mathrm{s}, \mathrm{OMe}), 4.43(1 \mathrm{H}, \mathrm{d}, J 10.99,3 \mathrm{~b}-\mathrm{H}), 4.65$ $\left(1 \mathrm{H}\right.$, br dd, 3a-H), $5.20(1 \mathrm{H}, \mathrm{m}, 4-\mathrm{H}) ; \delta_{\mathrm{H}}\left(400 \mathrm{MHz}, \mathrm{d}_{6}\right.$-acetone $)$ $1.78(3 \mathrm{H}, \mathrm{d}, J 6.59, \mathrm{Me}), 3.98,3.99$ and $4.07(3 \times 3 \mathrm{H}, 3 \times \mathrm{s}$, $3 \times \mathrm{OMe}), 4.75(1 \mathrm{H}, \mathrm{dd}, J 11.99$ and $1.10,3 \mathrm{~b}-\mathrm{H}), 5.05(1 \mathrm{H}, \mathrm{dd}$, $J 11.99$ and $2.75,3 \mathrm{a}-\mathrm{H}), 5.36(1 \mathrm{H}, \mathrm{m}, 4-\mathrm{H}) ; \delta_{\mathrm{C}}\left(\mathrm{C}_{6} \mathrm{D}_{6}, 100 \mathrm{MHz}\right)$ $17.23(\mathrm{Me}), 49.46(4-\mathrm{C}), 51.88(\mathrm{OMe}), 52.09(\mathrm{OMe}), 52.22$ (OMe), 69.41 (3-C), 120.71 (7-C), 121.98 (8-C), 122.87 (6-C), 123.63 (8a-C), $155.10,159.39,162.99,163.46\left(3 \times \mathrm{CO}_{2} \mathrm{Me}\right.$ and $\mathrm{C}=\mathrm{O}), v_{\max } / \mathrm{cm}^{-1} 1716,1721,1737,1755,(4 \times \mathrm{C}=\mathrm{O}), 1554$ $(\mathrm{C}=\mathrm{N}) ; m / z 325\left(\mathrm{M}^{\cdot+}\right), 294$ (base), 236.

X-Ray crystal structure determination of 14.§ The structure was solved by direct methods, SHELXS-97, ${ }^{16}$ and refined by full matrix least squares using SHELXL-97. ${ }^{17}$ SHELX operations were rendered paperless using ORTEX which was also used to obtain the drawings. ${ }^{18}$ Data were corrected for Lorentz and polarization effects but not for absorption. Hydrogen atoms were included in calculated positions with thermal parameters $30 \%$ larger than the atom to which they were attached. The non-hydrogen atoms were refined anisotropically. All calculations were performed on a Pentium PC. Crystal data for $\mathbf{1 4}$ are given in Table 3.

\section{Dimethyl 7-methyl-4-oxo-3a-phenyl-3a,4,6,7-tetrahydro- isoxazolo[3,2-c][1,4]oxazine-2,3-dicarboxylates $12 \mathrm{~b}$ and 15}

Freshly recrystallised nitrone $\mathbf{1 b}(0.19 \mathrm{~g}, 0.93 \mathrm{mmol})$ and dimethyl acetylenedicarboxylate $(0.18 \mathrm{~g}, 1.27 \mathrm{mmol})$ were stirred in $\mathrm{CHCl}_{3}\left(23 \mathrm{~cm}^{3}\right)$ at reflux under a nitrogen atmosphere for $40 \mathrm{~h}$. The reaction mixture was allowed to cool to rt and the solvent was removed under reduced pressure. The yellow oily residue was purified by flash chromatography $\left(\mathrm{Et}_{2} \mathrm{O}\right.$-petroleum spirit, 1 : 1), yielding 12b (178 mg, 56\%), $15(17.5 \mathrm{mg}, 6 \%)$ and unreacted nitrone $(0.05 \mathrm{~g}, 26 \%)$. Compound $\mathbf{1 2 b}$ : colourless cubic crystals, $\mathrm{mp} 159-162^{\circ} \mathrm{C}$ (from $\mathrm{CHCl}_{3}$-hexane) (Found: $\mathrm{C}$, 58.82; $\mathrm{H}, 4.99 ; \mathrm{N}, 4.40 . \mathrm{C}_{17} \mathrm{H}_{17} \mathrm{NO}_{7}$ requires: $\mathrm{C}, 58.79 ; \mathrm{H}, 4.90$;

§CCDC reference numbers 168302 and 168303. See http:// www.rsc.org/suppdata/p1/b1/b106832f/ for crystallographic files in .cif or other electronic format. 
Table 3 Crystal data and structure refinement ${ }^{a}$ for $\mathbf{1 4}$

$\begin{array}{ll}\text { Empirical formula } & \mathrm{C}_{14} \mathrm{H}_{15} \mathrm{NO}_{8} \\ \text { Formula weight } & 325.27 \\ \text { Temperature/K } & 293(2) \\ \text { Crystal system } & \text { Monoclinic } \\ \text { Space group } & P 2_{1} / a \\ \text { Unit cell dimensions } & a=9.917(2) \AA \\ & b=11.620(3) \AA \\ & c=13.983(4) \AA \\ & \beta=107.40(2)^{\circ} \\ \text { Volume } & 1537.4(7) \AA^{3} \\ Z & 4 \\ \text { Density (calculated) } & 1.405 \mathrm{Mg} \mathrm{m}^{-3} \\ \text { Absorption coefficient } & 0.117 \mathrm{~mm}^{-1} \\ \text { Independent reflections } & 1880[R(\mathrm{int})=0.0150] \\ \text { Final } R \text { indices }[I>2 \sigma(I)] & R_{1}=0.0365, w R_{2}=0.0934\end{array}$

${ }^{a} R$ indices: $R_{1}=\left[\Sigma|| F_{\mathrm{o}}|-| F_{\mathrm{c}} \mid\right] / \Sigma\left|F_{\mathrm{o}}\right|$ (based on $\left.F\right), w R_{2}=\left[\left[\Sigma_{w}\left(\mid F_{\mathrm{o}}{ }^{2}-\right.\right.\right.$ $\left.\left.\left.F_{2-\mathrm{C}}\right)^{2}\right] /\left[\Sigma_{w}\left(F_{\mathrm{o}}{ }^{2}\right)^{2}\right]\right]^{1 / 2}\left(\right.$ based on $\left.F^{2}\right) . w=1 /\left[\left(\sigma F_{\mathrm{o}}\right)^{2}+(0.0569 P)^{2}\right]$. Goodnessof-fit $=\left[\Sigma_{w}\left(F_{\mathrm{o}}^{2}-F_{2-\mathrm{C}}\right)^{2} /\left(N_{\mathrm{obs}}-N_{\text {parameters }}\right)\right]^{1 / 2}$.

Table 4 Crystal data and structure refinement ${ }^{a}$ for $\mathbf{1 2 b}$

$\begin{array}{ll}\text { Empirical formula } & \mathrm{C}_{17} \mathrm{H}_{17} \mathrm{NO}_{7} \\ \text { Formula weight } & 347.32 \\ \text { Temperature/K } & 293(2) \\ \text { Crystal system } & \text { Orthorhombic } \\ \text { Space group } & P 2_{1} \\ \text { Unit cell dimensions } & a=9.023(3) \AA \\ & b=11.0408(16) \AA \\ & c=16.112(3) \AA \\ \text { Volume } & \beta=89.976(19)^{\circ} \\ Z & 1605.1(6) \AA^{3} \\ \text { Density (calculated) } & 4 \\ \text { Absorption coefficient } & 1.437 \mathrm{Mg} \mathrm{m}^{-3} \\ \text { Independent reflections } & 0.113 \mathrm{~mm}^{-1} \\ \text { Final } R \text { indices }[I>2 \sigma(I)] & 1823[R(\mathrm{int})=0.0583] \\ & R_{1}=0.0501, w R_{2}=0.1127\end{array}$

${ }^{a} R$ indices: $R_{1}=\left[\Sigma|| F_{\mathrm{o}}|-| F_{\mathrm{c}}||\right] / \Sigma\left|F_{\mathrm{o}}\right|($ based on $F), w R_{2}=\left[\left[\Sigma_{w}\left(\mid F_{\mathrm{o}}{ }^{2}-\right.\right.\right.$ $\left.\left.\left.F_{2-\mathrm{C}}\right)^{2}\right] /\left[\Sigma_{w}\left(F_{\mathrm{o}}\right)^{2}\right]\right]^{1 / 2}\left(\right.$ based on $\left.F^{2}\right) . w=1 /\left[\left(\sigma F_{\mathrm{o}}\right)^{2}+(0.0569 P)^{2}\right]$. Goodnessof-fit $=\left[\Sigma_{w}\left(F_{\mathrm{o}}{ }^{2}-F_{2-\mathrm{C}}\right)^{2} /\left(N_{\mathrm{obs}}-N_{\text {parameters }}\right)\right]^{1 / 2}$.

$\mathrm{N}, 4.04 \%) ; \delta_{\mathrm{H}}(400 \mathrm{MHz}) 1.32(3 \mathrm{H}, \mathrm{d}, J 6.35, \mathrm{Me}), 3.62(1 \mathrm{H}, \mathrm{m}$, $7-\mathrm{H}), 3.66(3 \mathrm{H}, \mathrm{s}, \mathrm{OMe}), 3.85(1 \mathrm{H}, \mathrm{dd}, J 11.96$ and $10.99,6 \mathrm{~b}-\mathrm{H})$, $3.89(3 \mathrm{H}, \mathrm{s}, \mathrm{OMe}), 4.14(1 \mathrm{H}, \mathrm{dd}, J 11.96$ and $3.17,6 \mathrm{a}-\mathrm{H}), 7.42$ $(3 \mathrm{H}, \mathrm{m}, m-$ and $p-\mathrm{Ar}-\mathrm{H}), 7.60(2 \mathrm{H}, \mathrm{m}, o-\mathrm{Ar}-\mathrm{H}) ; \delta_{\mathrm{C}}(100 \mathrm{MHz})$ $15.73(\mathrm{Me}), 52.16$ and $53.27(2 \times \mathrm{OMe}), 58.62(7-\mathrm{C}), 67.40$ (6-C), 79.59 (3a-C), 111.86 (3-C), 127.10, 128.63, 128.97 (Ar-C), 137.84 (quaternary $n$-Ar-C), 149.18 (2-C), 158.39, 161.66 and $167.82\left(2 \times \mathrm{CO}_{2} \mathrm{Me}\right.$ and $\left.\mathrm{C}=\mathrm{O}\right)$.

NOEDS results for $\mathbf{1 2 b}$ : irradiation of $7-\mathrm{Me}$ caused a $4.9 \%$ enhancement on $7-\mathrm{H}$ and $1.2 \%$ on $6 \mathrm{a}-\mathrm{H}$ and $0.8 \%$ on each of the Ar-H signals.

X-Ray crystal structure determination of $12 \mathrm{~b} . \S$ As for compound 14. Crystal data for $\mathbf{1 2 b}$ are given in Table 4.

Compound 15: a brown-orange gum which solidified on standing (decomposed $118{ }^{\circ} \mathrm{C}$ ) (combustion analysis is obtained as an enriched mixture of 12b with 15. Found: C, 58.80; $\mathrm{H}, 4.64 ; \mathrm{N}, 3.84 . \mathrm{C}_{16} \mathrm{H}_{17} \mathrm{NO}_{7}$ requires: $\mathrm{C}, 58.78 ; \mathrm{H}, 4.89$; $\mathrm{N}, 4.03 \%) ; \delta_{\mathrm{H}}(400 \mathrm{MHz}) 1.31(3 \mathrm{H}, \mathrm{d}, J 6.60,7-\mathrm{Me}), 3.63(3 \mathrm{H}, \mathrm{s}$, $\mathrm{OMe}), 3.72(1 \mathrm{H}, \mathrm{m}, 7-\mathrm{H}), 3.93(3 \mathrm{H}, \mathrm{s}, \mathrm{OMe}), 4.33(1 \mathrm{H}, \mathrm{dd}$, $J 11.90$ and $3.30,6 \mathrm{a}-\mathrm{H}), 4.68(1 \mathrm{H}, \mathrm{dd}, J 11.90$ and $9.52,6 \mathrm{~b}-\mathrm{H})$, $7.37(3 \mathrm{H}, \mathrm{m}, m-$ and $p-\mathrm{Ar}-\mathrm{H}), 7.54(2 \mathrm{H}, \mathrm{m}, o-\mathrm{Ar}-\mathrm{H}) ; \delta_{\mathrm{C}}(100$ $\mathrm{MHz}$, obtained for an enriched mixture of $\mathbf{1 2 b}$ with 15) 13.40 (7-Me), 52.98 and $53.74(2 \times \mathrm{OMe}), 58.96(7-\mathrm{C}), 68.90(6-\mathrm{C})$, 79.77 (3a-C), 111.65 (3-C), 128.13, 128.21, 128.81 (Ar-C), 137.09 (quaternary $n$-Ar-C), 153.09 (2-C), 158.61, 162.01 and $166.64\left(2 \times \mathrm{CO}_{2} \mathrm{Me}\right.$ and $\left.\mathrm{C}=\mathrm{O}\right)$.

NOEDS results for 15: irradiation of 7-H gave an enhancement of $8.10 \%$ onto $7-\mathrm{Me}$ and $2.17 \%$ onto $6 \mathrm{a}-\mathrm{H}$. Irradiation of $6 \mathrm{a}-\mathrm{H}$ gave an enhancement of $26.76 \%$ onto its partner $6 b-\mathrm{H}$
2,3-Dimethoxycarbonyl-8-methyl-3a-phenyl-7,8-dihydro-6 $\mathrm{H}$ isoxazolo[3,2-c][1,4]oxazepin- $4(3 \mathrm{a} H)$-one 16

The nitrone 1c $(0.55 \mathrm{~g}, 2.50 \mathrm{mmol})$ and dimethyl acetylenedicarboxylate $(0.46 \mathrm{~g}, 3,25 \mathrm{mmol})$ were stirred in $\mathrm{CHCl}_{3}\left(20 \mathrm{~cm}^{3}\right)$ at reflux under a nitrogen atmosphere for $32 \mathrm{~h}$. The reaction mixture was allowed to cool to $\mathrm{rt}$ and the reaction solvent removed under reduced pressure. The yellow oily residue was purified by flash chromatography $\left(\mathrm{Et}_{2} \mathrm{O}\right.$-petroleum spirit, 1.5 : $1.0)$ to give $16(0.79 \mathrm{~g}, 87 \%)$ and unchanged nitrone $(0.07 \mathrm{~g}$, $12 \%$ ). Compound 16: colourless cubic crystals (from $\mathrm{C}_{6} \mathrm{H}_{6}-$ petroleum spirit), $\mathrm{mp} 145-146{ }^{\circ} \mathrm{C}$ (Found: $\mathrm{C}, 60.08 ; \mathrm{H}, 7.12 ; \mathrm{N}$, $5.22 \% . \mathrm{C}_{18} \mathrm{H}_{19} \mathrm{NO}_{7}$ requires: $\mathrm{C}, 59.83 ; \mathrm{H}, 7.28 ; \mathrm{N}, 5.36 \%$; $\delta_{\mathrm{H}}(270 \mathrm{MHz}) 1.42(3 \mathrm{H}, \mathrm{d}, J 5.87, \mathrm{Me}), 2.24$ and $1.67(2 \times 1 \mathrm{H}$, $2 \times \mathrm{m}, 7 \mathrm{a}-\mathrm{H}$ and $7 \mathrm{~b}-\mathrm{H}), 3.60(1 \mathrm{H}, \mathrm{m}, 8-\mathrm{H}), 3.85$ and 3.67 $(2 \times 3 \mathrm{H}, 2 \times \mathrm{s}, 2 \times \mathrm{OMe}), 3.88(2 \mathrm{H}, \mathrm{m}, 6 \mathrm{a}-\mathrm{H}$ and $6 \mathrm{~b}-\mathrm{H}), 7.40$ $(3 \mathrm{H}, \mathrm{m}, m-$ and $p-\mathrm{Ar}-\mathrm{H}), 7.62(2 \mathrm{H}, \mathrm{m}, o-\mathrm{Ar}-\mathrm{H}) ; \delta_{\mathrm{C}}(67.5 \mathrm{MHz})$ $19.6(\mathrm{Me}), 36.6(7-\mathrm{C}), 51.9$ and $53.2(2 \times \mathrm{OMe}), 57.2(8-\mathrm{C}), 64.0$ (6-C), 86.7 (3a-C), 113.1 (3-C), 126.3-134.8 (Ar-C), 138.0 (2-C), 159.7, 164.3 and $168.6\left(2 \times \mathrm{CO}_{2} \mathrm{Me}\right.$ and $\left.\mathrm{C}=\mathrm{O}\right)$.

\section{1-Methylprop-2-enyl 2-oxopropanoate 17a}

Pyruvic acid (5.07 g, $57.6 \mathrm{mmol}$ ) and but-3-en-2-ol (4.98 g, 69.2 mmol) were heated for $5 \mathrm{~h}$ at reflux in $\mathrm{C}_{6} \mathrm{H}_{6}\left(200 \mathrm{~cm}^{3}\right)$ in the presence of a catalytic amount of $p$-TsOH $(0.55 \mathrm{~g}, 2.89 \mathrm{mmol})$ using a Dean-Stark apparatus. The reaction was allowed to cool to $\mathrm{rt}$ and was washed with sat. $\mathrm{NaHCO}_{3}\left(2 \times 150 \mathrm{~cm}^{3}\right)$ and then with water $\left(2 \times 150 \mathrm{~cm}^{3}\right)$. The organic layers were collected and dried (anhydrous $\mathrm{Na}_{2} \mathrm{SO}_{4}$ ), filtered and concentrated to yield the crude product as a yellow, pungent, mobile oil (6.56 g, $80.2 \%)$ which was not purified further. $\delta_{\mathrm{H}}(400 \mathrm{MHz}) 1.35(3 \mathrm{H}$, dd, $J 6.21$ and 2.01, OCMe), $2.39(3 \mathrm{H}, \mathrm{s}, \mathrm{Me}), 5.14(1 \mathrm{H}, \mathrm{dd}$, $J 1.10$ and $\left.10.62,=\mathrm{CH}_{2}\right), 5.25\left(1 \mathrm{H}, \mathrm{dd}, J 1.10\right.$ and $\left.17.21,=\mathrm{CH}_{2}\right)$, $5.37(1 \mathrm{H}, \mathrm{M}, \mathrm{CH}=), 5.81(1 \mathrm{H}, \mathrm{m}, \mathrm{OCH})$.

\section{1-Methylprop-2-enyl 2-(hydroxyimino)propanoate 17b}

The $\alpha$-keto ester 17a (6 g, $42.2 \mathrm{mmol})$, pyridine (5.01 g, 63.4 $\mathrm{mmol})$ and $\mathrm{NH}_{2} \mathrm{OH} \cdot \mathrm{HCl}(4.40 \mathrm{~g}, 63.3 \mathrm{mmol})$ were stirred in EtOH $\left(600 \mathrm{~cm}^{3}\right)$ at $\mathrm{rt}$ for $15 \mathrm{~h}$. The mixture was concentrated and taken up in $\mathrm{CH}_{2} \mathrm{Cl}_{2}\left(300 \mathrm{~cm}^{3}\right)$ and washed with water $\left(2 \times 150 \mathrm{~cm}^{3}\right)$. The organic layers were collected, dried (anhydrous $\mathrm{Na}_{2} \mathrm{SO}_{4}$ ), filtered and concentrated to yield the product, colourless plates $\left(5.97 \mathrm{~g}, 90 \%\right.$ ), $\mathrm{mp} 56.5-58.5^{\circ} \mathrm{C}$ (from $\mathrm{C}_{6} \mathrm{H}_{6}$-hexane) (Found: $\mathrm{C}, 53.72 ; \mathrm{H}, 6.79 ; \mathrm{N}, 8.69 . \mathrm{C}_{7} \mathrm{H}_{11} \mathrm{NO}_{3}$ requires: $\mathrm{C}, 53.50 ; \mathrm{H}, 7.01 ; \mathrm{N}, 8.92 \%) ; \delta_{\mathrm{H}}(400 \mathrm{MHz}) 1.38(3 \mathrm{H}$, d, $J$ 6.22, OCMe), $2.09(3 \mathrm{H}, \mathrm{s}, \mathrm{Me}), 5.16(1 \mathrm{H}, \mathrm{dd}, J 10.62$ and $\left.0.91,=\mathrm{CH}_{2}\right), 5.28\left(1 \mathrm{H}, \mathrm{dd}, J 17.21\right.$ and $\left.0.91,=\mathrm{CH}_{2}\right), 5.47(1 \mathrm{H}$, $\mathrm{m}, \mathrm{OCH}), 5.87(1 \mathrm{H}, \mathrm{m}, \mathrm{CH}=), 10.64(1 \mathrm{H}, \mathrm{br} \mathrm{s}, \mathrm{OH}) ; \delta_{\mathrm{C}}(100$ $\mathrm{MHz}) 10.42$ (OCMe), $19.81(\mathrm{Me}), 72.75(\mathrm{OC}), 116.57\left(=\mathrm{CH}_{2}\right)$, $136.91(\mathrm{CH}=), 149.18(\mathrm{C}=\mathrm{N}), 162.85(\mathrm{C}=\mathrm{O})$.

\section{2,3,5-Trimethyl-6-oxo-3,6-dihydro-2H-1,4-oxazin-4-ium-4- olates 18 and 19}

Oxime 17b (1.2 g, $7.64 \mathrm{mmol})$ was heated at reflux in xylene $\left(410 \mathrm{~cm}^{3}\right)$ in the presence of hydroquinone $(1 \% \mathrm{w} / \mathrm{v}, 4.1 \mathrm{~g})$ under a nitrogen atmosphere for $51 \mathrm{~h}$. The reaction mixture was allowed to cool to $\mathrm{rt}$ and the precipitated hydroquinone was filtered off. The filtrate was concentrated and taken up in $\mathrm{CHCI}_{3}\left(10 \mathrm{~cm}^{3}\right)$, and further hydroquinone precipitated, which was again removed by filtration. The filtrate was concentrated to yield the crude product, a black viscous oil. Purification by flash chromatography $\left(\mathrm{Et}_{2} \mathrm{O}\right.$-petroleum spirit, $\left.4: 1\right)$ afforded 18 $(624 \mathrm{mg}, 52 \%), 19(190 \mathrm{mg}, 16 \%)$ and unreacted oxime 17b (260 mg, 22\%).

Compound 18: colourless cubic crystals, $\mathrm{mp} 82-84{ }^{\circ} \mathrm{C}$ (from $\mathrm{CHCl}_{3}$-hexane) (Found: C, 53.76; $\mathrm{H}, 7.01 ; \mathrm{N}, 8.59 . \mathrm{C}_{7} \mathrm{H}_{11} \mathrm{NO}_{3}$ requires: $\mathrm{C}, 53.50 ; \mathrm{H}, 7.01 ; \mathrm{N}, 8.92 \%) ; \delta_{\mathrm{H}}(400 \mathrm{MHz}) 1.51(3 \mathrm{H}$, d, $J 6.59,6-\mathrm{Me}), 1.53(3 \mathrm{H}, \mathrm{d}, J 6.60,5-\mathrm{Me}), 2.22(3 \mathrm{H}, \mathrm{s}, 3-\mathrm{Me})$, 
$3.91(1 \mathrm{H}, \mathrm{m}, 5-\mathrm{H}), 4.45(1 \mathrm{H}, \mathrm{m}, 6-\mathrm{H}) ; \delta_{\mathrm{C}}(100 \mathrm{MHz}) 11.95$ (6-Me), 14.29 (5-Me), 18.41 (3-Me), 67.74 (5-C), 75.05 (6-C), $134.83(3-\mathrm{C}), 159.03(\mathrm{C}=\mathrm{O})$.

NOEDS results for 18: irradiation of $5-\mathrm{H}$ caused a $0.68 \%$ enhancement on $6-\mathrm{H}$ and $5.14 \%$ enhancement on the signal representing 5-Me and 6-Me. $\mathrm{m} / \mathrm{z} 57$ (base), 68, 85, 113, 157 $\left(\mathrm{M}^{+}\right)$.

Compound 19: a brown mobile oil which solidified on standing (Found: $\mathrm{C}, 53.55 ; \mathrm{H}, 6.83 ; \mathrm{N}, 8.67 . \mathrm{C}_{7} \mathrm{H}_{11} \mathrm{NO}_{3}$ requires: $\mathrm{C}$, $53.50 ; \mathrm{H}, 7.01 ; \mathrm{N}, 8.92 \%) ; \delta_{\mathrm{H}}(400 \mathrm{MHz}) 1.42(3 \mathrm{H}, \mathrm{d}, J 6.59$, 6-Me), 1.47 (3H, d, J 6.96, 5-Me), $2.20(3 \mathrm{H}, \mathrm{s}, 3-\mathrm{Me}), 3.97(1 \mathrm{H}$, $\mathrm{m}, 5-\mathrm{H}), 4.82(1 \mathrm{H}, \mathrm{m}, 6-\mathrm{H}) ; \delta_{\mathrm{C}}(100 \mathrm{MHz}) 11.61(6-\mathrm{Me}), 11.83$ (5-Me), 15.69 (3-Me), 68.30 (5-C), 72.37 (6-C), 134.23 (3-C), $159.62(\mathrm{C}=\mathrm{O})$.

NOEDS results for 19: irradiation of $5-\mathrm{H}$ caused a $3.93 \%$ enhancement on $6-\mathrm{H}$ and irradiation of $6-\mathrm{H}$ caused a $4.11 \%$ enhancement on the signal representing $5-\mathrm{H}$.

\section{Dimethyl 3a,6,7-trimethyl-4-oxo-3a,4,6,7-tetrahydroisoxazolo- [3,2-c][1,4] oxazine-2,3-dicarboxylate 20 and trimethyl 3,4- dimethyl-1-oxo-3,4,6,7-tetrahydro-1 $H$-pyrrolo[2,1-c][1,4]- oxazine-6,7,8-tricarboxylate 22}

(i) Nitrone 18 ( $0.050 \mathrm{~g}, 0.318 \mathrm{mmol})$ and dimethyl acetylenedicarboxylate $(0.090 \mathrm{~g}, 0.63 \mathrm{mmol})$ were stirred in $\mathrm{CHCl}_{3}\left(5 \mathrm{~cm}^{3}\right)$ at reflux under a nitrogen atmosphere for $7.5 \mathrm{~h}$. The reaction mixture was allowed to cool to $\mathrm{rt}$, was concentrated under reduced pressure and purified by flash chromatography $\left(\mathrm{Et}_{2} \mathrm{O}-\right.$ petroleum spirit, $1: 2)$ yielding $20(134 \mathrm{mg}, 74 \%)$. Compound 20: colourless needle-like crystals, $\mathrm{mp} 157-159.5{ }^{\circ} \mathrm{C}$ (from $\mathrm{CHCl}_{3}$-hexane) (Found: $\mathrm{C}, 51.81 ; \mathrm{H}, 5.53 ; \mathrm{N}, 4.23 . \mathrm{C}_{13} \mathrm{H}_{17} \mathrm{NO}_{7}$ requires: $\mathrm{C}, 52.17 ; \mathrm{H}, 5.68 ; \mathrm{N}, 4.68 \%) ; \delta_{\mathrm{H}}(400 \mathrm{MHz}) 1.28(3 \mathrm{H}$, d, $J 5.86,7-\mathrm{Me}), 1.40$ (3H, d, J 6.59, 6-Me), $1.82(3 \mathrm{H}, \mathrm{s}, 3 \mathrm{a}-\mathrm{Me})$, $3.07(1 \mathrm{H}, \mathrm{m}, 7-\mathrm{H}), 3.83(3 \mathrm{H}, \mathrm{s}, \mathrm{OMe}), 3.85(3 \mathrm{H}, \mathrm{s}, \mathrm{OMe}), 4.21$ $(1 \mathrm{H}, \mathrm{m}, 6-\mathrm{H}) ; \delta_{\mathrm{C}}(100 \mathrm{MHz}) 15.14(7-\mathrm{Me}), 17.47$ (6-Me), 26.94 (3a-Me), 52.71 (OMe), $53.10(\mathrm{OMe}), 61.21$ (7-C), 74.71 (3a-C), 75.26 (6-C), 115.55 (3-C), 145.32 (2-C), 158.01, 162.13 and $167.65\left(2 \times \mathrm{CO}_{2} \mathrm{Me}\right.$ and $\left.\mathrm{C}=\mathrm{O}\right)$.

NOEDS results for 20: irradiation of 3a-Me caused a $1.27 \%$ enhancement of $6-\mathrm{H}$ and 0.2 on 7-H. Irradiation of 6-H caused the following enhancements $4.30 \%$ on $6-\mathrm{Me}, 2.73$ on $7-\mathrm{Me}, 2.07$ on $3 \mathrm{a}-\mathrm{Me}$ and 1.63 on $7-\mathrm{H}$. Irradiation of the signal for $7-\mathrm{H}$ caused the following enhancements $1.95 \%$ on $6-\mathrm{Me}, 4.53$ on 7-Me and 1.60 on 6-H.

(ii) When the reaction was repeated, on twice the scale of (i) above, and extending the reaction time to $24 \mathrm{~h}$, adduct 20 (134 mg, 72\%) and trimethyl 3,4-dimethyl-1-oxo-3,4,6,7-tetrahydro-1 $H$-pyrrolo[2,1-c][1,4]oxazine-6,7,8-tricarboxylate 22 (27 $\mathrm{mg}, 15 \%$ ) were obtained; data for $\mathbf{2 0}$ as reported above.

Compound 22: a yellow amorphous solid, mp 103-108 ${ }^{\circ} \mathrm{C}$ $\left(\mathrm{CHCl}_{3}\right.$-hexane) (Found: C, 52.74; $\mathrm{H}, 5.37 ; \mathrm{N}, 3.57 . \mathrm{C}_{15} \mathrm{H}_{17} \mathrm{NO}_{8}$ requires: $\mathrm{C}, 53.10 ; \mathrm{H}, 5.01 ; \mathrm{N}, 4.13 \%) ; \delta_{\mathrm{H}}(400 \mathrm{MHz}) 1.39$ $(3 \mathrm{H}, \mathrm{d}, J 6.96,4-\mathrm{Me}), 1.58(3 \mathrm{H}, \mathrm{d}, J 6.59,3-\mathrm{Me}), 3.91(9 \mathrm{H}, \mathrm{s}$, $3 \times \mathrm{OMe}), 4.72(1 \mathrm{H}, \mathrm{m}, 4-\mathrm{H}), 5.03(1 \mathrm{H}, \mathrm{m}, 3-\mathrm{H}) ; \delta_{\mathrm{C}}(100 \mathrm{MHz})$ 19.21 (4-Me), 20.32 (3-Me), 52.71 (4-C), 52.80 and 53.69 (OMe), 76.70 (3-C), 120.27, 121.45, 122.03, 124.17, (6-C, 7-C, $8-\mathrm{C}, 8 \mathrm{a}-\mathrm{C}), 154.38,159.41,162.43$ and $164.00\left(3 \times \mathrm{CO}_{2} \mathrm{Me}\right.$ and $\mathrm{C}=\mathrm{O}) ; \mathrm{m} / \mathrm{z}$ 55, 236, 308 (base), $339\left(\mathrm{M}^{+}\right)$.

(iii) Nitrone $18(0.05 \mathrm{~g}, 0.318 \mathrm{mmol})$ and dimethyl acetylenedicarboxylate $(0.09 \mathrm{~g}, 0.64 \mathrm{mmol})$ were stirred in $\mathrm{CHCl}_{3}\left(5 \mathrm{~cm}^{3}\right)$ at $\mathrm{rt}$ under a nitrogen atmosphere for $7 \mathrm{~d}$. The reaction mixture was concentrated and purified by flash chromatography $\left(\mathrm{Et}_{2} \mathrm{O}-\right.$ petroleum spirit, $1: 2)$ yielding $20(90.3 \mathrm{mg}, 95 \%)$ which crystallised as colourless needle-like crystals, data agree with those reported above.

(iv) When the reaction was repeated, at $\mathrm{rt}$, on twice the scale of (iii) above, extending the reaction time to $10 \mathrm{~d}$, adduct 20 (157.5 mg, 83\%) and trimethyl 3,4-dimethyl-1-oxo-3,4,6,7tetrahydro- $1 H$-pyrrolo[2,1-c][1,4]oxazine-6,7,8-tricarboxylate $22(15.3 \mathrm{mg}, 8 \%)$ were obtained; data as reported above.
Dimethyl 3,4-dimethyl-1-oxo-3,4-dihydro-1 $H$-pyrrolo[2,1-c][1,4] oxazine-6,7-dicarboxylate 21

The adduct 20 (50 $\mathrm{mg}, 0.167 \mathrm{mmol})$ was stirred with heating under vigorous reflux in the minimum amount of $\mathrm{CHCl}_{3}$ $\left(1 \mathrm{~cm}^{3}\right)$ for $48 \mathrm{~h}$. The reaction was allowed to cool to $\mathrm{rt}$ and the solvent removed under reduced pressure. The crude product was purified by flash chromatography $\left(\mathrm{Et}_{2} \mathrm{O}\right.$-petroleum spirit; $1: 2)$ yielding $21(35.5 \mathrm{mg}, 76 \%)$, which crystallised as colourless needles, $\mathrm{mp} 118-120{ }^{\circ} \mathrm{C}$ (from $\mathrm{Et}_{2} \mathrm{O}$-petroleum spirit) (Found: $\mathrm{C}, 55.84 ; \mathrm{H}, 5.26 ; \mathrm{N}, 4.81 . \mathrm{C}_{13} \mathrm{H}_{15} \mathrm{NO}_{6}$ requires: $\mathrm{C}$, $55.52 ; \mathrm{H}, 5.34 ; \mathrm{N}, 4.98 \%) ; \delta_{\mathrm{H}}(400 \mathrm{MHz}) 1.38(3 \mathrm{H}, \mathrm{d}, J 6.87$, 4-Me), 1.56 (3H, d, J 6.78, 3-Me), 3.87 (3H, s, OMe), $3.95(3 \mathrm{H}$, s, OMe $), 4.71(1 \mathrm{H}, \mathrm{q}, J 6.87,4-\mathrm{H}), 4.86(1 \mathrm{H}, \mathrm{q}, J 6.78,3-\mathrm{H})$, $7.35(1 \mathrm{H}, \mathrm{s}, 8-\mathrm{H}) ; \delta_{\mathrm{C}}(100 \mathrm{MHz}) 19.34$ (4-Me), 20.61 (3-Me), 52.20 (4-C), 52.71 (OMe), 53.18 (OMe), 78.10 (3-C), 117.97 (8-C), 120.65, 121.79 and 125.75 (7-C, 6-C and 8a-C), 156.87 , 159.67 and $163.66\left(2 \times \mathrm{CO}_{2} \mathrm{Me}\right.$ and $\left.\mathrm{C}=\mathrm{O}\right) ; \mathrm{m} / \mathrm{z} 281\left(\mathrm{M}^{++}\right), 250$.

\section{Methyl 3a,7-dimethyl-4-oxo-3a,4,6,7-tetrahydroisoxazolo[3,2- c] $[1,4]$ oxazine-3-carboxylate 23a and methyl 3a,7-dimethyl-4- oxo-3a,4,6,7-tetrahydroisoxazolo $[3,2-c][1,4]$ oxazine-2- carboxylate $24 a$}

The nitrone 1a $(0.10 \mathrm{~g}, 0.69 \mathrm{mmol})$ and methyl propiolate $(0.29 \mathrm{~g}, 3.49 \mathrm{mmol})$ were stirred in $\mathrm{CHCl}_{3}\left(10 \mathrm{~cm}^{3}\right)$ at reflux under a nitrogen atmosphere for $25 \mathrm{~h}$. The reaction mixture was allowed to cool to $\mathrm{rt}$ and the reaction solvent and unreacted dipolarophile were removed under reduced pressure, yielding the crude product as an orange-brown oil. The residue was purified by flash chromatography $\left(\mathrm{Et}_{2} \mathrm{O}\right.$-petroleum spirit, $\left.1: 2\right)$, yielding 24a (36.5 mg, 23\%), 23a ( $88.5 \mathrm{mg}, 56 \%)$ and unreacted dipole (19 mg, 19\%).

Compound 24a: colourless cubic crystals, $\mathrm{mp} 88-90^{\circ} \mathrm{C}$ (from $\mathrm{CHCl}_{3}$-hexane) (Found: C, 52.57; H, 5.96; N, 6.09. $\mathrm{C}_{10} \mathrm{H}_{13} \mathrm{NO}_{5}$ requires: $\mathrm{C}, 52.86 ; \mathrm{H}, 5.73 ; \mathrm{N}, 6.16 \%) ; \delta_{\mathrm{H}}(400 \mathrm{MHz}) 1.28(3 \mathrm{H}$, $\mathrm{d}, J$ 6.35, 7-Me), $1.66(3 \mathrm{H}, \mathrm{s}, 3 \mathrm{a}-\mathrm{Me}), 3.32(1 \mathrm{H}, \mathrm{m}, 7-\mathrm{H}), 3.85$ $(3 \mathrm{H}, \mathrm{s}, \mathrm{OMe}), 4.05(1 \mathrm{H}, \mathrm{dd}, J 11.96$ and $2.93,6 \mathrm{a}-\mathrm{H}), 4.25(1 \mathrm{H}$, dd, $J 11.96$ and $2.93,6 \mathrm{a}-\mathrm{H}), 6.00(1 \mathrm{H}, \mathrm{s}, 3-\mathrm{H}) ; \delta_{\mathrm{C}}(100 \mathrm{MHz})$ 14.93 (7-Me), 27.58 (3a-Me), 52.54 (OMe), 54.96 (7-C), 68.21 (6-C), 73.82 (3a-C), 112.67 (3-C), 144.89 (2-C), 158.73 and $168.84\left(\mathrm{CO}_{2} \mathrm{Me}\right.$ and $\left.\mathrm{C}=\mathrm{O}\right)$; DEPT $135(400 \mathrm{MHz}) 14.93(7-\mathrm{Me})$, 27.58 (3a-Me), 52.54 (OMe), 54.96 (7-C), 68.21 (6-C), 112.67 (3-C).

NOEDS results for 24a: irradiation of $6 \mathrm{a}-\mathrm{H}$ caused an enhancement of $4.1 \%$ on $7-\mathrm{H}, 2.9 \%$ onto $7-\mathrm{Me}$ and $22.5 \%$ on its partner $6 \mathrm{~b}-\mathrm{H}$. Irradiation of $6 \mathrm{~b}-\mathrm{H}$ caused an $18.8 \%$ enhancement on its partner $6 \mathrm{a}-\mathrm{H}, 2 \%$ enhancement on $7-\mathrm{H}$ and no enhancement on either 7-Me or 3a-Me.

Compound 23a: a viscous yellow oil (Found: C, 52.74; $\mathrm{H}$, 5.68; N, 6.34. $\mathrm{C}_{10} \mathrm{H}_{13} \mathrm{NO}_{5}$ requires: $\mathrm{C}, 52.86 ; \mathrm{H}, 5.73 ; \mathrm{N}, 6.16 \%$ ); $\delta_{\mathrm{H}}(400 \mathrm{MHz}) 1.29(3 \mathrm{H}, \mathrm{d}, J 6.84,7-\mathrm{Me}), 1.82(3 \mathrm{H}, \mathrm{s}, 3 \mathrm{a}-\mathrm{Me})$, $3.48(1 \mathrm{H}, \mathrm{m}, 7-\mathrm{H}), 3.75(3 \mathrm{H}, \mathrm{s}, \mathrm{OMe}), 4.16(1 \mathrm{H}, \mathrm{dd}, J 12.02$ and 6.71, 6b-H), $4.46(1 \mathrm{H}, \mathrm{dd}, J 12.02$ and $2.69,6 \mathrm{a}-\mathrm{H}), 7.48(1 \mathrm{H}, \mathrm{s}$, $2-\mathrm{H}) ; \delta_{\mathrm{C}}(100 \mathrm{MHz}) 15.18$ (7-Me), $26.86(3 \mathrm{a}-\mathrm{Me}), 51.40(\mathrm{OMe})$, 57.68 (7-C), 67.15 (6-C), 70.12 (3a-C), 109.31 (3-C), 154.53 (2-C), 162.47 and $167.86\left(\mathrm{CO}_{2} \mathrm{Me}\right.$ and $\left.\mathrm{C}=\mathrm{O}\right)$; DEPT 135 (400 MHz) 15.18 (7-Me), 26.86 (3a-Me), 51.40 (OMe), 57.68 (7-C), 67.15 (6-C), 154.53 (2-C).

NOEDS results for 23a: irradiation of $6 \mathrm{~b}-\mathrm{H}$ caused a $19 \%$ enhancement on its partner $6 \mathrm{a}-\mathrm{H}$, and a $1.8 \%$ enhancement on 7 -Me. Irradiation of 3a-Me caused a $0.55 \%$ enhancement on $6 \mathrm{~b}-\mathrm{H}$. Irradiation of $6 \mathrm{a}-\mathrm{H}$ caused an enhancement of $4 \%$ on $7-\mathrm{H}$ and $20 \%$ on its partner $6 \mathrm{~b}-\mathrm{H}$.

(ii) When the above reaction was repeated extending the duration to $82 \mathrm{~h}$ heating crude ${ }^{1} \mathrm{H}$ NMR spectral analysis showed 24a, 23a, 25, 25i, 13 plus $13 \mathbf{i}$ present in a $3:$ trace : 15 : $4: 25$ ratio. 25 is characterised by a separate experiment (see below) and $25 \mathbf{i}$ is proposed on the basis of a pair of doublets, 6.96 and $7.05 \mathrm{ppm}$ each with $J$ value $(\sim 4.4 \mathrm{~Hz})$ characteristic of the ortho-coupled aromatic protons. Adducts $\mathbf{1 3}$ and $\mathbf{1 3 i}$ are 
characterised as a mixture $\delta_{\mathrm{H}}(400 \mathrm{MHz}) 1.56(6 \mathrm{H}, 2 \times$ overlapping $\mathrm{d}, \mathrm{Me}[\mathbf{1 3}$ and 13i] $), 3.87 \& 3.94(2 \times 3 \mathrm{H}, 2 \times \mathrm{s}, 2 \times \mathrm{OMe}$ [13]), $3.89 \& 3.90(2 \times 3 \mathrm{H}, 2 \times \mathrm{s}, 2 \times \mathrm{OMe}[13 \mathrm{i}]), 4.44(1 \mathrm{H}$, $2 \times$ overlapping d, 3b-H [13 and 13i]), $4.65(2 \mathrm{H}, \mathrm{m}, 3 \mathrm{a}-\mathrm{H}$ [13 and 13i]), $5.05(1 \mathrm{H}, \mathrm{m}, 4-\mathrm{H}[\mathbf{1 3}]), 5.35$ (1H, m, 4-H [13]), 7.36 $(2 \mathrm{H}, \mathrm{s}, \mathrm{Ar}-\mathrm{H}[\mathbf{1 3}$ and 13i]).

\section{Methyl 4-methyl-1-oxo-3,4-dihydro-1 $H$-pyrrolo[2,1-c][1,4]- oxazine-7-carboxylate 25}

The adduct 24a (59 mg, $0.26 \mathrm{mmol})$ in $\mathrm{CHCl}_{3}\left(1 \mathrm{~cm}^{3}\right)$ was held at vigorous reflux under a nitrogen atmosphere for $56 \mathrm{~h}$. The resulting mixture was concentrated under reduced pressure and purification by flash chromatography $\left(\mathrm{Et}_{2} \mathrm{O}\right.$-petroleum spirit, $1: 1)$ yielded 25 as fine colourless needles $(21.6 \mathrm{mg}, 40 \%), \mathrm{mp}$ 127.5-128.0 ${ }^{\circ} \mathrm{C}$ (from $\mathrm{C}_{6} \mathrm{H}_{6}$-petroleum spirit) (Found: $\mathrm{C}, 57.42$; $\mathrm{H}, 5.55 ; \mathrm{N}, 6.38 . \mathrm{C}_{10} \mathrm{H}_{11} \mathrm{NO}_{4}$ requires: $\mathrm{C}, 57.42 ; \mathrm{H}, 5.26 ; \mathrm{N}$, $6.70 \%) ; \delta_{\mathrm{H}}(400 \mathrm{MHz}) 1.59(3 \mathrm{H}, \mathrm{d}, J 6.59, \mathrm{Me}), 3.84(3 \mathrm{H}, \mathrm{s}$, OMe), 4.29 (1H, dd, $J 11.53$ and 7.87, 3b-H), $4.42(1 \mathrm{H}, \mathrm{m}, 4-\mathrm{H})$, $4.55(1 \mathrm{H}$, dd, $J 11.53$ and $3.48,3 \mathrm{a}-\mathrm{H}), 7.49$ and $7.52(2 \times 1 \mathrm{H}$, $2 \times \mathrm{d}, J 1.46,6-\mathrm{H}$ and $8-\mathrm{H}) ; \delta_{\mathrm{C}}(100 \mathrm{MHz}) 15.94(\mathrm{Me}), 49.23$ (4-C), 51.52 (OMe), 71.01 (3-C), 118.06 (7-C), 118.69 (8-C), 119.76 (8a-C), 126.00 (6-C), 157.88 and $163.83\left(\mathrm{CO}_{2} \mathrm{Me}\right.$ and $\mathrm{C}=\mathrm{O})$.

\section{Methyl 4-methyl-1-oxo-3,4-dihydro-1 $H$-pyrrolo[2,1-c][1,4]- oxazine-6-carboxylate 26 a}

The adduct 23a (63 mg, $0.28 \mathrm{mmol}$ ) was stirred in $\mathrm{CHCl}_{3}$ (3 $\mathrm{cm}^{3}$ ) with heating at reflux under a $\mathrm{N}_{2}$ atm for $82 \mathrm{~h}$. The mixture was allowed to cool to $\mathrm{rt}$ and the solvent removed under reduced pressure. Purification of the crude mixture by flash chromatography (petroleum spirit- $\mathrm{Et}_{2} \mathrm{O}, 2: 1$ ) afforded the title compound 26a (14 mg, 24\%) and returned 23a ( $8 \mathrm{mg}, 12 \%)$. 26a, colourless cubic crystals, $\mathrm{mp} 138-140{ }^{\circ} \mathrm{C}$ (from $\mathrm{CHCl}_{3}$ ). $\left(R_{\mathrm{f}} 0.676, \mathrm{Et}_{2} \mathrm{O}\right) ; \delta_{\mathrm{H}}(400 \mathrm{MHz}) 1.54(3 \mathrm{H}, \mathrm{d}, J 6.83,4-\mathrm{Me})$, $3.89(3 \mathrm{H}, \mathrm{s}, \mathrm{OMe}), 4.43(1 \mathrm{H}, \mathrm{d}, J 11.71,3 \mathrm{a}-\mathrm{H}), 4.65(1 \mathrm{H}, \mathrm{dd}$, $J 11.71$ and 3.90, 3b-H), $5.29(1 \mathrm{H}, \mathrm{m}, 4-\mathrm{H}), 6.95(1 \mathrm{H}, \mathrm{d}, J 3.90$, 8-H), $7.05\left(1 \mathrm{H}, \mathrm{d}, J\right.$ 3.90, 7-H); $\delta_{\mathrm{C}}(100 \mathrm{MHz}) 18.79$ (4-Me), 48.64 (4-C), 51.86 (OMe), 71.01 (3-C), 116.57 (7-C), 117.46 (8-C), 123.20 (8a-C), 124.30 (6-C), 158.27 (1-C), 160.69 $\left(\mathrm{CO}_{2} \mathrm{Me}\right)$.

\section{Methyl 7-methyl-4-oxo-3a-phenyl-3a,4,6,7-tetrahydroisoxazolo- $[3,2-c][1,4]$ oxazine-2-carboxylate $24 b$ and methyl 7-methyl-4- oxo-3a-phenyl-3a,4,6,7-tetrahydroisoxazolo $[3,2-c][1,4]$ oxazine- 3-carboxylates $23 \mathrm{~b}$ and $23 \mathrm{c}$}

Freshly recrystallised nitrone $1 \mathbf{b}(0.11 \mathrm{~g}, 0.54 \mathrm{mmol})$ and methyl propiolate $(0.25 \mathrm{~g}, 3.02 \mathrm{mmol})$ were stirred in $\mathrm{CHCl}_{3}\left(15 \mathrm{~cm}^{3}\right)$ at reflux under a nitrogen atmosphere for $40 \mathrm{~h}$. The reaction mixture was allowed to cool to $\mathrm{rt}$ and the solvent removed under reduced pressure yielding the crude product, a viscous yellow oil which was purified by flash chromatography $\left(\mathrm{Et}_{2} \mathrm{O}\right.$ petroleum spirit, $1: 2)$, yielding 24b (26.1 mg, 17\%), 23b (48.8 $\mathrm{mg}, 31 \%)$ and $23 \mathrm{c}(19.2 \mathrm{mg}, 13 \%)$ and unreacted nitrone (47 mg, 43\%).

Compound 24b: colourless cubic crystals, mp $122-125{ }^{\circ} \mathrm{C}$ (from $\mathrm{CHCl}_{3}$-hexane) (Found: $\mathrm{C}, 62.08 ; \mathrm{H}, 4.94 ; \mathrm{N}, 4.96$. $\mathrm{C}_{15} \mathrm{H}_{15} \mathrm{NO}_{5}$ requires: $\left.\mathrm{C}, 62.28 ; \mathrm{H}, 5.19 ; \mathrm{N}, 4.84 \%\right) ; \delta_{\mathrm{H}}(400$ MHz) $1.40(3 \mathrm{H}, \mathrm{d}, J 6.35,7-\mathrm{Me}), 3.54(1 \mathrm{H}, \mathrm{m}, 7-\mathrm{H}), 3.82(3 \mathrm{H}, \mathrm{s}$, OMe), $4.04(1 \mathrm{H}, \mathrm{dd}, J 11.96$ and $10.74,6 \mathrm{~b}-\mathrm{H}), 4.20(1 \mathrm{H}$, dd, $J 11.96$ and $2.93,6 \mathrm{a}-\mathrm{H}), 6.26(1 \mathrm{H}, \mathrm{s}, 3-\mathrm{H}), 7.34-7.42(3 \mathrm{H}, \mathrm{m}$, $o$ - and $p$-Ar-H), $7.67(2 \mathrm{H}, \mathrm{m}, m-\mathrm{Ar}-\mathrm{H}) ; \delta_{\mathrm{C}}(100 \mathrm{MHz}) 15.67$ (7-Me), 52.65 (OMe), 57.06 (7-C), 67.98 (6-C), 79.6 (3a-C), 111.75 (3-C), 126.27, 128.35, 128.78 and 129.03 (Ar-C), 144.61 (2-C), 158.75 and $167.50\left(\mathrm{CO}_{2} \mathrm{Me}\right.$ and $\left.\mathrm{C}=\mathrm{O}\right)$.

NOEDS results for $\mathbf{2 4 b}$ : irradiation of $6 \mathrm{~b}-\mathrm{H}$ caused a $3.5 \%$ enhancement on the Ar-H signal, 21\% enhancement on its partner $6 \mathrm{a}-\mathrm{H}$ and $2 \%$ enhancement on 7-Me. Irradiation of $7-\mathrm{Me}$ caused a $0.6 \%$ enhancement on Ar-H. Irradiation of
$6 \mathrm{a}-\mathrm{H}$ caused an enhancement of $3.9 \%$ on $7-\mathrm{H}$ and $11 \%$ on its partner $6 b-\mathrm{H}$.

Compound 23b: a colourless viscous oil (Found: C, 61.92; H, 5.09; $\mathrm{N}, 4.84 . \mathrm{C}_{15} \mathrm{H}_{15} \mathrm{NO}_{5}$ requires: $\mathrm{C}, 62.28 ; \mathrm{H}, 5.19 ; \mathrm{N}, 4.84 \%$ ); $\delta_{\mathrm{H}}(400 \mathrm{MHz}) 1.30(3 \mathrm{H}, \mathrm{d}, J 6.35,7-\mathrm{Me}), 3.57(1 \mathrm{H}, \mathrm{m}, 7-\mathrm{H})$, $3.59(3 \mathrm{H}, \mathrm{s}, \mathrm{OMe}), 3.73(1 \mathrm{H}, \mathrm{dd}, J 11.96$ and $11.23,6 \mathrm{~b}-\mathrm{H})$, $4.05(1 \mathrm{H}, \mathrm{dd}, 11.96$ and $3.17,6 \mathrm{a}-\mathrm{H}), 7.40(3 \mathrm{H}, \mathrm{m}, o-$ and $p$-Ar-H), $7.48(1 \mathrm{H}, \mathrm{s}, 2-\mathrm{H}), 7.60(2 \mathrm{H}, \mathrm{m}, m-\mathrm{Ar}-\mathrm{H}) ; \delta_{\mathrm{C}}(67.5$ $\mathrm{MHz}) \quad 16.26 \quad$ (7-Me), 51.19 (OMe), $59.85 \quad$ (7-C), 66.94 (6-C), 76.87 (3a-C), 110.47 (quaternary $n$-Ar-C), 127.30-128.63 $(5 \times$ Ar-C), 138.31 (3-C), $152.86(2-\mathrm{C}), 162.41$ and 168.48 $\left(\mathrm{CO}_{2} \mathrm{Me}\right.$ and $\left.\mathrm{C}=\mathrm{O}\right)$.

NOEDS results for 23b: irradiation of $6 \mathrm{~b}-\mathrm{H}$ caused a $3 \%$ enhancement on the Ar-H signal and 20\% enhancement on its partner $6 \mathrm{a}-\mathrm{H}$.

Compound 23c: a brown-orange viscous oil (Found: $\mathrm{C}$, 62.20; $\mathrm{H}, 5.06 ; \mathrm{N}, 4.61 . \mathrm{C}_{15} \mathrm{H}_{15} \mathrm{NO}_{5}$ requires: $\mathrm{C}, 62.28 ; \mathrm{H}, 5.19$; $\mathrm{N}, 4.84 \%) ; \delta_{\mathrm{H}}(400 \mathrm{MHz}) 1.22(3 \mathrm{H}, \mathrm{d}, J 6.71,7-\mathrm{Me}), 3.57(3 \mathrm{H}, \mathrm{s}$, $\mathrm{OMe}), 3.65(1 \mathrm{H}, \mathrm{m}, 7-\mathrm{H}), 4.24(1 \mathrm{H}, \mathrm{dd}, J 11.60$ and $3.05,6 \mathrm{a}-\mathrm{H})$, $4.57(1 \mathrm{H}$, dd, $J 9.77$ and 11.60, 6b-H), $7.19(1 \mathrm{H}, \mathrm{s}, 2-\mathrm{H}), 7.34$ $(3 \mathrm{H}, \mathrm{m}, o$ - and $p-\mathrm{Ar}-\mathrm{H}), 7.42(2 \mathrm{H}, \mathrm{d}, J 1.22, m-\mathrm{Ar}-\mathrm{H}) ; \delta_{\mathrm{C}}(100$ $\mathrm{MHz}) 13.52$ (7-Me), 51.48 (7-C), 52.84 (OMe), 68.51 (6-C), 75.64 (3a-C), 110.75 (3-C), 127.78-128.67 (Ar-C), 137.38 (quaternary $n$-Ar-C), 155.89 (2-C), 162.21 and $166.67\left(\mathrm{CO}_{2} \mathrm{Me}\right.$ and $\mathrm{C}=\mathrm{O}$ ).

\section{3-Methoxycarbonyl-8-methyl-3a-phenyl-7,8-dihydro-6 $\mathrm{H}$ - isoxazolo[3,2-c][1,4]oxazepin-4(3aH)-one 27 and 2-methoxy- carbonyl-8-methyl-3a-phenyl-7,8-dihydro-6H-isoxazolo[3,2-c]- $[1,4]$ oxazepin-4(3aH)-one 28}

Freshly recrystallised nitrone $1 \mathrm{c}(0.46 \mathrm{~g}, 2.10 \mathrm{mmol})$ was stirred in neat methyl propiolate $\left(5 \mathrm{~cm}^{3}, 4.73 \mathrm{~g}, 56.0 \mathrm{mmol}\right)$ under a nitrogen atmosphere at $65^{\circ} \mathrm{C}$ for $36 \mathrm{~h}$. Unreacted dipolarophile was removed under reduced pressure $\left(100{ }^{\circ} \mathrm{C}, 15 \mathrm{mmHg}\right)$ to leave a viscous yellow oil. The crude products were separated by flash chromatography $\left(\mathrm{Et}_{2} \mathrm{O}\right.$-petroleum spirit, $\left.1.0: 1.8\right)$ yielding $28(0.38 \mathrm{~g}, 60 \%), 27(0.15 \mathrm{~g}, 24 \%)$ and unreacted dipole (0.06 g, $13 \%)$.

Compound 28: colourless prisms, mp 133-134 ${ }^{\circ} \mathrm{C}$ (from $\mathrm{C}_{6} \mathrm{H}_{6}$-petroleum spirit) (Found: C, 63.09; H, 5.76; N, 4.48. $\mathrm{C}_{16} \mathrm{H}_{17} \mathrm{NO}_{5}$ requires: $\left.\mathrm{C}, 63.37 ; \mathrm{H}, 5.61 ; \mathrm{N}, 4.62 \%\right) ; \delta_{\mathrm{H}}(270$ $\mathrm{MHz}) 1.44(3 \mathrm{H}, \mathrm{d}, J 5.86, \mathrm{Me}), 1.75(1 \mathrm{H}, \mathrm{m}, 7 \mathrm{~b}-\mathrm{H}), 2.23(1 \mathrm{H}$, $\mathrm{m}, 7 \mathrm{a}-\mathrm{H}), 3.52(1 \mathrm{H}, \mathrm{m}, 8-\mathrm{H}), 3.78(3 \mathrm{H}, \mathrm{s}, \mathrm{OMe}), 3.90(1 \mathrm{H}, \mathrm{m}$, $J 12.45$ and $6.60,6 \mathrm{~b}-\mathrm{H}), 4.10(1 \mathrm{H}, \mathrm{m}, 6 \mathrm{a}-\mathrm{H}), 6.19(1 \mathrm{H}, \mathrm{s}, 3-\mathrm{H})$, $7.38(3 \mathrm{H}, \mathrm{m}, m-$ and $p-\mathrm{Ar}-\mathrm{H}), 7.62(2 \mathrm{H}, \mathrm{m}, o-\mathrm{Ar}-\mathrm{H}) ; \delta_{\mathrm{C}}(67.5$ $\mathrm{MHz}) 19.8$ (Me), 36.8 (7-C), 52.6 (OMe), 55.9 (8-C), 63.9 (6-C), 86.5 (3a-C), 113.6 (3-C), 125.0-138.5 (Ar-C), 142.5 (2-C), 159.0 and $169.7\left(\mathrm{CO}_{2} \mathrm{Me}\right.$ and $\left.\mathrm{C}=\mathrm{O}\right)$.

Compound 27: colourless rods, $\mathrm{mp} 130-131^{\circ} \mathrm{C}$ (from $\mathrm{C}_{6} \mathrm{H}_{6}-$ petroleum spirit) (Found: $\mathrm{C}, 63.20 ; \mathrm{H}, 5.49 ; \mathrm{N}, 4.49 . \mathrm{C}_{16} \mathrm{H}_{17} \mathrm{NO}_{5}$ requires: $\mathrm{C}, 63.37 ; \mathrm{H}, 5.61 ; \mathrm{N}, 4.62 \%) ; \delta_{\mathrm{H}}(270 \mathrm{MHz}) 1.44(3 \mathrm{H}$, d, J 5.86, Me), $1.64(1 \mathrm{H}, \mathrm{m}, 7 \mathrm{~b}-\mathrm{H}), 2.21(1 \mathrm{H}, \mathrm{m}, 7 \mathrm{a}-\mathrm{H}), 3.50$ $(1 \mathrm{H}, \mathrm{m}, 8-\mathrm{H}), 3.60(3 \mathrm{H}, \mathrm{s}, \mathrm{OMe}), 3.86(2 \mathrm{H}, \mathrm{m}, 6 \mathrm{~b}-\mathrm{H}, 6 \mathrm{a}-\mathrm{H})$, $7.35(4 \mathrm{H}, \mathrm{m}, m-$ and $p-\mathrm{Ar}-\mathrm{H}$ and $2-\mathrm{H}), 7.65(2 \mathrm{H}, \mathrm{m}, o-\mathrm{Ar}-\mathrm{H})$; $\delta_{\mathrm{C}}(67.5 \mathrm{MHz}) 18.9(\mathrm{Me}), 36.4(7-\mathrm{C}), 53.3(\mathrm{OMe}), 55.6(8-\mathrm{C})$, 64.1 (6-C), 86.9 (3a-C), 110.4 (3-C), 125.9-138.5 (Ar-C), 152.9 $(2-\mathrm{C}), 158.6$ and $168.6\left(\mathrm{CO}_{2} \mathrm{Me}\right.$ and $\left.\mathrm{C}=\mathrm{O}\right)$.

\section{Methyl 3a,6,7-trimethyl-4-oxo-3a,4,6,7-tetrahydroisoxazolo- [3,2-c][1,4]oxazine-3-carboxylate 29 and methyl 3a,6,7-tri- methyl-4-oxo-3a,4,6,7-tetrahydroisoxazolo[3,2-c][1,4]oxazine- 2-carboxylate 30}

Nitrone $18(0.2 \mathrm{~g}, 1.27 \mathrm{mmol})$ and methyl propiolate $(0.535 \mathrm{~g}$, $6.37 \mathrm{mmol})$ were heated at reflux in $\mathrm{CHCl}_{3}\left(20 \mathrm{~cm}^{3}\right)$ under a nitrogen atmosphere for $30 \mathrm{~h}$. The reaction was allowed to cool to $\mathrm{rt}$ and the solvent and excess dipolarophile were removed under reduced pressure. The resulting mixture was purified by flash chromatography $\left(\mathrm{Et}_{2} \mathrm{O}\right.$-petroleum spirit, $\left.1: 2\right)$ yielding 
30 (60.7 mg, 20\%), 29 (117.7 mg, 38\%) and unreacted nitrone (57.9 mg, 29\%).

Compound 30: a colourless oil which solidified in the cold, mp 89-92 ${ }^{\circ} \mathrm{C}$ (Found: C, 54.96; H, 6.13; N, 5.65. $\mathrm{C}_{11} \mathrm{H}_{15} \mathrm{NO}_{5}$ requires: $\mathrm{C}, 54.77 ; \mathrm{H}, 6.22 ; \mathrm{N}, 5.81 \%) ; \delta_{\mathrm{H}}(400 \mathrm{MHz}) 1.28(3 \mathrm{H}$, $\mathrm{d}, J 6.22,7-\mathrm{Me}), 1.38(3 \mathrm{H}, \mathrm{d}, J 6.59,6-\mathrm{Me}), 1.64(3 \mathrm{H}, \mathrm{s}, 3 \mathrm{a}-\mathrm{Me})$, $2.97(1 \mathrm{H}, \mathrm{m}, 7-\mathrm{H}), 3.83(3 \mathrm{H}, \mathrm{s}, \mathrm{OMe}), 4.17(1 \mathrm{H}, \mathrm{m}, 6-\mathrm{H})$, $6.01(1 \mathrm{H}, \mathrm{s}, 3-\mathrm{H}) ; \delta_{\mathrm{H}}(400 \mathrm{MHz})\left(\mathrm{C}_{6} \mathrm{D}_{6}\right) 0.73(3 \mathrm{H}, \mathrm{d}, J 6.39$, 7-Me), $0.83(3 \mathrm{H}, \mathrm{d}, J$ 6.39, 6-Me), 1.45 (3H, s, 3a-Me), 2.41 $(1 \mathrm{H}, \mathrm{m}, 7-\mathrm{H}), 3.25(3 \mathrm{H}, \mathrm{s}, \mathrm{OMe}), 3.45(1 \mathrm{H}, \mathrm{m}, 6-\mathrm{H}), 6.00$ $(1 \mathrm{H}, \mathrm{s}, 3-\mathrm{H}) ; \delta_{\mathrm{C}}(100 \mathrm{MHz}) 15.31(7-\mathrm{Me}), 17.47$ (6-Me), 27.45 (3a-Me), 52.54 (OMe), 60.65 (7-C), 73.65 (3a-C), 75.51 (6-C), 112.92 (3-C), 144.59 (2-C), 158.86 and $169.26\left(\mathrm{CO}_{2} \mathrm{Me}\right.$ and $\mathrm{C}=\mathrm{O}) ; \mathrm{m} / \mathrm{z}$ 110, 142 (base), 154, 170, 182, 198, $241\left(\mathrm{M}^{+}\right)$, $242(\mathrm{M}+1)$.

NOEDS results for 30 (recorded in $\mathrm{C}_{6} \mathrm{D}_{6}$ ): irradiation of $3 \mathrm{a}-\mathrm{Me}$ caused a $1.14 \%$ enhancement on $6-\mathrm{H}$ and 0.9 on $3-\mathrm{H}$. Irradiation of $7-\mathrm{H}$ caused the following enhancements $3.39 \%$ on $6-\mathrm{Me}$ and 4.06 on $7-\mathrm{Me}$. Irradiation of the signal for $6-\mathrm{H}$ caused the following enhancements $3.26 \%$ on $7-\mathrm{Me}, 1.05$ on $3 \mathrm{a}-\mathrm{Me}$ and 1.27 on $7-\mathrm{H}$.

Compound 29: brown needles, mp $98-102{ }^{\circ} \mathrm{C}$ (from $\mathrm{CHCl}_{3}$ hexane) (Found: $\mathrm{C}, 54.82 ; \mathrm{H}, 6.18 ; \mathrm{N}, 5.55 . \mathrm{C}_{11} \mathrm{H}_{15} \mathrm{NO}_{5}$ requires: $\mathrm{C}, 54.77 ; \mathrm{H}, 6.22 ; \mathrm{N}, 5.81 \%) ; \delta_{\mathrm{H}}(400 \mathrm{MHz}) 1.25(3 \mathrm{H}$, $\mathrm{d}, J 6.22,7-\mathrm{Me}), 1.38(3 \mathrm{H}, \mathrm{d}, J 6.22,6-\mathrm{Me}), 1.83(3 \mathrm{H}, \mathrm{s}, 3 \mathrm{a}-\mathrm{Me})$, $3.01(1 \mathrm{H}, \mathrm{m}, 7-\mathrm{H}), 3.75(3 \mathrm{H}, \mathrm{s}, \mathrm{OMe}), 4.24(1 \mathrm{H}, \mathrm{m}, 6-\mathrm{H}), 7.34$ $(1 \mathrm{H}, \mathrm{s}, 2-\mathrm{H}) ; \delta_{\mathrm{C}}(100 \mathrm{MHz}) 15.99(7-\mathrm{Me}), 17.56$ (6-Me), 26.86 (3a-Me), 51.40 (OMe), 63.97 (7-C), 71.06 (3a-C), 73.69 (6-C), 109.57 (3-C), 152.96 (2-C), 162.89 and $169.39\left(\mathrm{CO}_{2} \mathrm{Me}\right.$ and $\mathrm{C}=\mathrm{O})$.

NOEDS results for 29: irradiation of 3a-Me caused a 2.54\% enhancement on $6-\mathrm{H}$ and $0.2 \%$ on $7-\mathrm{H}$. Irradiation of $7-\mathrm{H}$ caused the following \% enhancements: 2.42 on 6-Me, 5.23 on $7-\mathrm{Me}$ and 1.18 on $6-\mathrm{H}$. Irradiation of the signal for $6-\mathrm{H}$ caused the following \% enhancements: 3.55 on $7-\mathrm{Me}, 4.79$ on $6-\mathrm{Me}$, 5.17 on $3 \mathrm{a}-\mathrm{Me}$ and 0.73 on $7-\mathrm{H}$.

(ii) When the above reaction was repeated, extending the duration to $84 \mathrm{~h}$ crude ${ }^{1} \mathrm{H}$ NMR spectral analysis showed 29, 30, 31 and 31i present in the ratio $10: 6: 2.6: 2$.

\section{Methyl 3,4-dimethyl-1-oxo-3,4-dihydro-1 $H$-pyrrolo[2,1-c][1,4]- oxazine-8-carboxylate 31}

The adduct 30 (58 mg, $0.24 \mathrm{mmol})$ was stirred with heating at vigorous reflux in $\mathrm{CHCl}_{3}\left(1 \mathrm{~cm}^{3}\right)$ for $80 \mathrm{~h}$. The reaction was allowed to cool to $\mathrm{rt}$ and the solvent removed under reduced pressure. The crude mixture was purified by flash chromatography $\left(\mathrm{Et}_{2} \mathrm{O}\right.$-petroleum spirit, $\left.1: 1\right)$ yielding 31 (36 mg, 67\%) and unreacted $30(9.6 \mathrm{mg}, 17 \%)$. Compound 31 crystallised to yellow cubic crystals, mp $129-132{ }^{\circ} \mathrm{C}$ (from $\mathrm{C}_{6} \mathrm{H}_{6}$-petroleum spirit) (Found: $\mathrm{C}, 58.82 ; \mathrm{H}, 5.79 ; \mathrm{N}, 5.65 . \mathrm{C}_{11} \mathrm{H}_{13} \mathrm{NO}_{4}$ requires: C, 59.19; H, 5.83; N, 6.28\%); $\delta_{\mathrm{H}}(400 \mathrm{MHz}) 1.52(3 \mathrm{H}, \mathrm{d}, J 6.59$, $4-\mathrm{Me}), 1.60(3 \mathrm{H}, \mathrm{d}, J 6.59,3-\mathrm{Me}), 3.84(3 \mathrm{H}, \mathrm{s}, \mathrm{OMe}), 4.07(1 \mathrm{H}$, $\mathrm{dq}, J 8.24$ and $6.59,4-\mathrm{H}), 4.46(1 \mathrm{H}, \mathrm{dq}, J 8.24$ and $6.59,3-\mathrm{H})$, $7.48(1 \mathrm{H}, \mathrm{d}, J 1.46,6-\mathrm{H}), 7.53(1 \mathrm{H}, \mathrm{d}, J 1.46,8-\mathrm{H}) ; \delta_{\mathrm{C}}(100$ MHz) 15.77 (4-Me), 17.77 (3-Me), 51.22 (OMe), 54.50 (4-C), 78.70 (3-C), 118.06 (7-C), 118.44 (8-C), 120.05 (8a-C), 125.79 $(6-\mathrm{C}), 157.73$ and $163.91\left(\mathrm{CO}_{2} \mathrm{Me}\right.$ and $\left.\mathrm{C}=\mathrm{O}\right)$.

\section{Methyl 3,4-dimethyl-1-oxo-3,4-dihydro-1 $H$-pyrrolo[2,1-c][1,4]- oxazine-6-carboxylate 26b}

The adduct 29 (0.12 g, $0.49 \mathrm{mmol})$ was stirred in $\mathrm{CHCl}_{3}\left(4 \mathrm{~cm}^{3}\right)$ with heating at reflux under a $\mathrm{N}_{2}$ atm for $84 \mathrm{~h}$. The mixture was allowed to cool to $\mathrm{rt}$ and the solvent removed under reduced pressure. Purification of the crude mixture by flash chromatography (petroleum spirit- $\mathrm{Et}_{2} \mathrm{O}, 2: 1$ ) afforded title compound (14 mg, 12.8\%) and returned 29 (38 mg, 32\%). 26b, colourless cubic crystals, $\mathrm{mp} 155-156^{\circ} \mathrm{C}$ (from $\mathrm{CHCl}_{3}$-hexane) (Found: $\mathrm{C}$,
58.90; H, 6.06; N, 5.98. $\mathrm{C}_{11} \mathrm{H}_{13} \mathrm{NO}_{4}$ requires: $\mathrm{C}, 59.19 ; \mathrm{H}, 5.87$; $\mathrm{N}, 6.27 \%) ; \delta_{\mathrm{H}}(400 \mathrm{MHz}) 1.36(3 \mathrm{H}, \mathrm{d}, J 6.35,4-\mathrm{Me}), 1.53(3 \mathrm{H}$, d, $J$ 6.35, 3-Me), 3.89 (3H, s, OMe), 4.70 (1H, quartet, $J 6.67$, 4-H), 5.12 (1H, quartet, $J 6.67,3-\mathrm{H}), 6.95(1 \mathrm{H}, \mathrm{d}, J 4.39,8-\mathrm{H})$, $7.03(1 \mathrm{H}, \mathrm{d}, J 4.39,7-\mathrm{H}) ; \delta_{\mathrm{C}}(100 \mathrm{MHz}) 19.43(4-\mathrm{Me}), 20.57$ (3-Me), 51.82 (4-C), 52.59 (OMe), 78.27 (3-C), 116.10 (7-C), 117.42 (8-C), 122.94 (8a-C), 124.64 (6-C), 157.42 (1-C), 161.37 $\left(\mathrm{CO}_{2} \mathrm{Me}\right)$.

\section{Acknowledgements}

This work has been supported by an Enterprise Ireland Postgraduate Award (JF), and the Chemistry Departments of the National University of Ireland Galway and the National University of Ireland, Maynooth.

\section{References}

1 For general reviews on nitrone cycloaddition chemistry, see: J. J. Tufariello, in 1,3-Dipolar Cycloaddition Reactions, ed. A. Padwa, Wiley, New York, 1984, vol. 2, p. 83; P. N. Confalone and E. M. Huie, Org. React. (N. Y.), 1988, 36, 1; W. Carruthers, in Cycloaddition Reactions in Organic Synthesis, Pergamon, Oxford, 1990 , p. 269.

2 C. O'Mahony and F. Heaney, Chem. Commun., 1996, 167; F. Heaney and C. O'Mahony, J. Chem. Soc., Perkin Trans. 1, 1998, 341.

3 N. Katagiri, A. Kurimoto, A. Yamada, H. Sato, T. Katsuhara, K. Takagi and C. Kaneko, J. Chem. Soc., Chem. Commun., 1994, 281; N. Katagiri, M. Okada, Y. Morishita and C. Kaneko, Tetrahedron, 1997, 53, 5725; S. Ham and D. Birney, Tetrahedron Lett., 1994, 35, 8113.

4 O. Tamura, K. Gotanda, R. Terashima, M. Kikuchi, T. Miyawaki and M. Sakamoto, Chem. Commun., 1996, 1861; O. Tamura, K. Gotanda, J. Yoshino, Y. Morita, R. Terashima, M. Kikuchi, T. Miyawaki, N. Mita, M. Yamashita, H. Ishibashi and M. Sakamoto, J. Org. Chem., 2000, 65, 8544.

5 (a) S. W. Baldwin, B. G. Young and A. T. McPhail, Tetrahedron Lett., 1998, 39, 6819; (b) R. E. Looper and R. M. Williams, Tetrahedron Lett., 2001, 42, 769.

6 R. C. Bernotas and G. Adams, Tetrahedron Lett., 1996, 37, 7339.

7 (a) L. M. Harwood, A. C. Manage, S. Robin, S. F. G. Hopes, D. Watkin and C. E. Williams, Synlett, 1993, 777; (b) L. M. Harwood and I. A. Lilly, Tetrahedron: Asymmetry, 1995, 6, 1557; (c) D. Alker, L. M. Harwood and C. E. Williams, Tetrahedron, 1997, 53, 12671; (d) D. Alker, G. Hamblett, L. M. Harwood, S. M. Robertson, D. J. Watkin and C. E. Williams, Tetrahedron, 1998, 54, 6089; (e) D. Alker, L. M. Harwood and C. E. Williams, Tetrahedron Lett., 1998, 39, 475; ( $f$ ) M. G. B. Drew, L. M. Harwood, D. W. Price, M.-S. Choi and G. Park, Tetrahedron Lett., 2000, 41, 5077.

8 F. Roussi, M. Bonin, A. Chiaroni, L. Micouin, C. Riche and H.-P. Husson, Tetrahedron Lett., 1999, 40, 3727.

9 S. A. Ali and M. I. M. Wazeer, J. Chem. Soc., Perkin Trans. 2, 1986, 1789; S. A. Ali and M. I. M. Wazeer, Tetrahedron, 1988, 44, 187.

10 (a) S. A. Ali and H. A. Almuallem, Tetrahedron, 1992, 48, 5273; (b) S. A. Ali and S. M. A. Hashmi, J. Chem. Soc., Perkin Trans. 2, 1998, 2699; (c) M. I. M. Wazeer, H. P. Perzanowski, S. I. Qureshi, M. B. Al-Murad and S. A. Ali, Tetrahedron, 2000, 56, 7229.

11 (a) J. P. Freeman, Chem. Rev., 1983, 83, 241; (b) for a recent example, see: N. Coșkun, F. T. Tat and Ö. Ö. Güven, Tetrahedron, 2001, 57, 3413; (c) W. Friebolin and W. Eberbach, Tetrahedron, 2001, 57, 4349; (d) B.-X. Zhao, Y. Yu and S. Eguchi, Tetrahedron, 1996, 52, 12049.

12 B. S. Jursic, J. Mol. Struct. (THEOCHEM), 1998, 454, 277.

13 O. Tamura, T. Kuroki, Y. Sakai, J.-I. Takizawa, J. Yoshino, Y. Morita, N. Mita, K. Gotanda and M. Sakamoto, Tetrahedron Lett., 1999, 40, 895 .

14 H. Günther, NMR Spectroscopy. Basic principles, concepts and applications in chemistry, 2nd edn., 1994, Wiley, New York, pp. 114 117.

15 K. N. Houk, A. Bimanand, D. Mukherjee, J. Sims, Y.-M. Chang, D. C. Kaufman and L. N. Domelsmith, Heterocycles, 1977, 7, 293; A. Liguori, R. Ottana, G. Romeo, G. Sindona and N. Uccella, Tetrahedron, 1998, 44, 1247.

16 G. M. Sheldrick, Acta Crystallogr., Sect. A, 1990, 46, 467.

17 G. M. Sheldrick, SHELXL-97 a computer program for crystal structure determination, University of Göttingen, 1997.

18 P. McArdle, J. Appl. Crystallogr., 1995, 28, 65. 